مجلة جامعة الملك عبدالعزيز: الآداب والعلوم الانسانية، م29ع3 ص ص: 257- 281 (2021م)

DOI:10.4197/Art.29-3.9

\title{
شعريَّة مستويات الحِجاج في دحض الإرهاب قصيدة (أَ كعبتي) نموذجًا
}

\author{
د. تيسير بنت عباس محمَّد الثَّريف \\ أستاذ البلاغة والنقد المساعد - قسم اللغة العربيَّة وآدابها \\ كلية الآداب والعلوم الإنسانية \\ جامعة الملك عبدالعزيز - جدة
}

مستخص. تعددت صور الإرهاب وطرقه، وتجاوز بجرمه تصوّر العقل البشري. ومن أكثر الأحداث الإرهابيَّة جرمًا

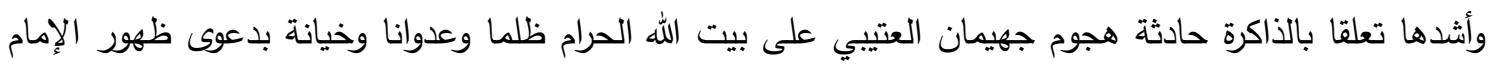
المهدي المنتظر ووجوب مبايعته، الأمر الذي هلكت بسببه العديد من الأرواح. هذا الحادث الأليم لقي إنكارًا وهياجًا من قبل المسلمين، وردود فعل متباينة كلٌّ حسب ما يستطيعه، فكانت ذي القصيدة -موضوع البحث- هي إحدى وسائل دحض الإرهاب ونكرانه باستدعاء أفانين مختلفة من الحجاج.

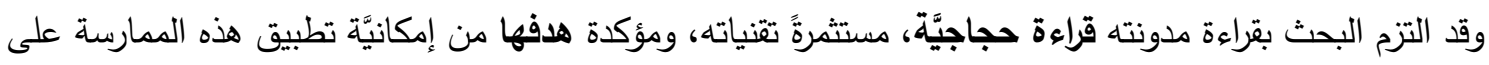

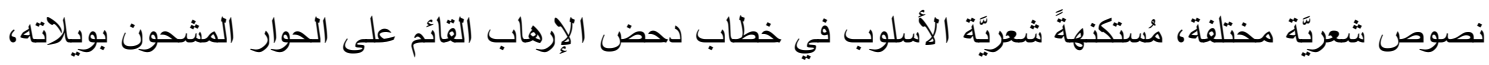
ومُبرزةً التقاء الحجاج بالشعريَّة بالإرهاب في إقناع المتلقي وإمتاعه في مستويات بنائيَّة متعددة، وأضرب مختلفة من

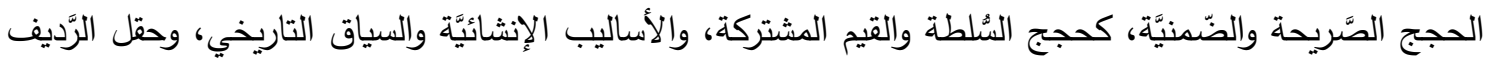
اللوني، والبنية الإيقاعية، وبنية التراكيب اللغويَّة.

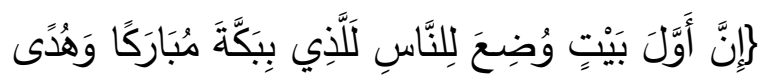
لَلْعَالَمِينَ 979

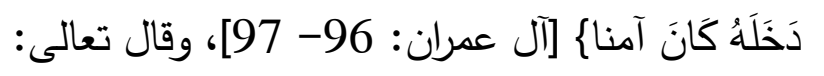

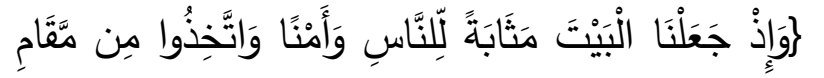

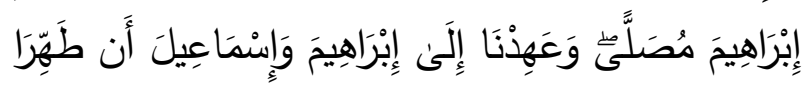

\section{المقدمة}

من الحوادث التي هزَّت العالم أجمع وعلى الأخص الحص

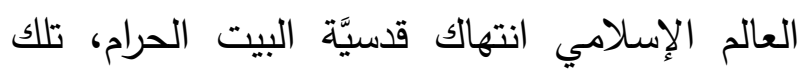

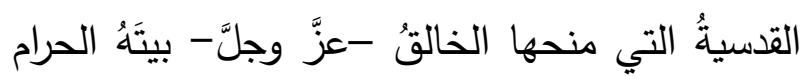
منذُ بدء الخليقة، قال تعالى: 
مملكتهم في البحرين آنذاك، وظلَّ أسيرًا لديهم اثنينِ وعشرين عامًا، ليعود بعدها إلى قراره وأمنهِ. 4 4- فتتة جهيمان العتيبي مع الزاعم أنَّه المهديّ المنتظر: في عهد الدولة السعودية تسلَّلت جماعةٌ

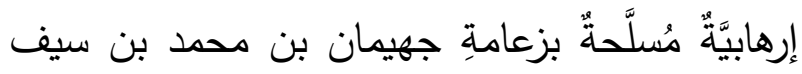
الحافي العتيبي 5 إلى المسجدِ الحرام (فجر يوم الثلاثاء غرة شهر محرَم عام 20 1400هـ-الموافق نوفمبر 1979م)، متَّخذة احتياطها بإدخال الأسلحة في نعوشٍ بحُجّة الصلاة على موتاهم بعد صـلاة الفجر ، وبعد الصَّلاةِ أمسك جهيمان (مكبّر الصوت) مُناديًا بمبايعة المهدي المزعوم قائلًا: أيهّها المسلمون في كل مكانٍ من العالم، هذا هو محمد بن عبد الله الإمام

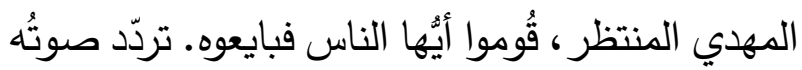
في أرجاءِ مكة المكرمة ومن ثم أرجاء العالم الإسلامي، وقامت جماعته بإغلاق أبواب المسجد الحرام وبحصار مَن فيه بعد أن فرَّ منهم من فرَّ ، ومن ضمنهم الشيخ السبيّل إمام المسجد الحرام الذي أبلغ الملك خالد بن عبد العزيز -رحمه الله-بالأمر • فكان لذلك النَّأ وقعُ أليم ومُفزع على الأمة الإسلامية، وكان موقفًا مُحرجًا ومحيّرًا للحكومةِ السعودية؛؛ فالعاثون في الأرض فسادًا يحاولون قلب نظام الحكم في البلاد؛ فأفسدوا في بلد

الأثير، اعتنى به: أبو صهيب الكرمي، (عمَّان- الرياض: بيت الأفكار

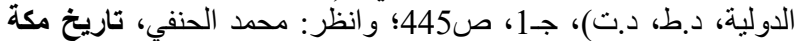

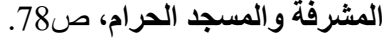

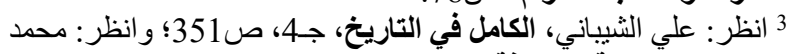

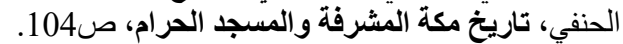

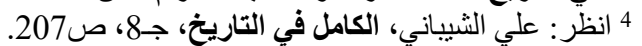

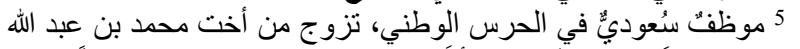

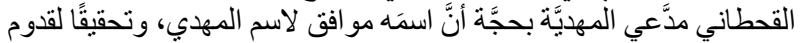
المجدّد الذّي يُبعثث على ر أس كل مائة عام.

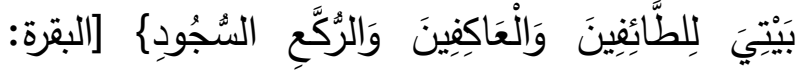
.$[125$ ومع ذلك تعرض البيت الحرام لسلسلةٍ من الانتهاكات المحرمة والغدرات الإجرامية عبر الزمن، منها: 1- يروي التاريخ الإسلامي أنَّ أوَّل هجومٍ كان على البيت الحرام عام الفيل (570 م)1 عندما عقد أبرهة الحبشي العزم على تدمير الكعبة، فسار إليها برفقة جنده والفيلة2ّ، وحمى اللهُ -عزَّ وجلـ- بيتهُ بالطير الأبابيل الرامية المعتدين بحجارٍ من سجيل. 2- في عهد عبد الملك بن مروان الخليفة الأموي حين أرسل جيشًا بقيادة الحجَّاج بن يوسف الثَّفي للتخلص من عبد الله بن الزبير الذي لجأ إلى الكعبة احتماءً بها، فما كان من الحجَّاج إلَّا أنْ ضرب الكعبةَّ بالمنجنيق ليحاصر ابن الزبير ويقضي عليه؛ فاحترقت الكعبة ودُكَّت أجزاء منها (عام 72هـ). 3- فتنة القرامطة (عام 317 هـ) في موسم الحج التي استمرت سبعة عشر يومًا، اعتدوا فيها على الحُجَّاج، وأعملوا فيهم قتلًا واستباحةً واغتصابًا، حتى قيل إنَّ عدد القتلى وصل إلى ثلاثين ألفا، وخلعوا باب الكعبة ونهبوا كسوتها واقتلعوا الحجر الأسود ورحلوا به إلى

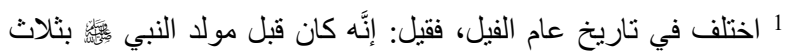

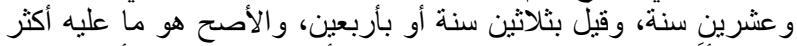

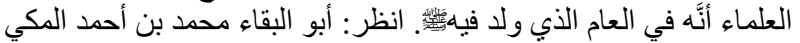

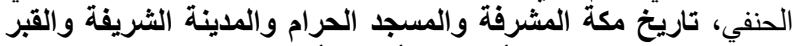

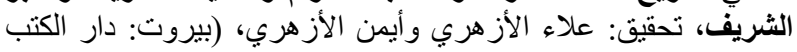

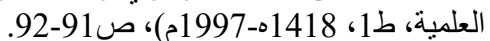

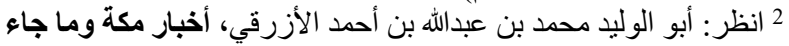

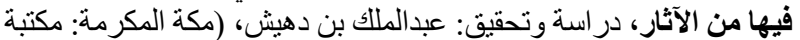

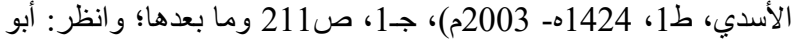
الحسن علي بن محمد الجزري الثيباني، الكامل في التاريخ- تاريخ ابن 
ومائة وتسعة مدنيين. بينما قُتل من أتباع جهيمان مائةٌ

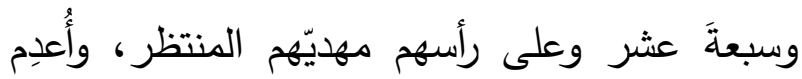

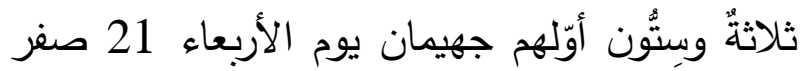
الموافق 9 يناير 1980م، ووُزّع الإعدام في مُدن مختلفة من المملكة، وتمّت بعدها إجراءات تطهير الحرم المكيّ، وعودةُ روح المسلمين بافتتاحه والصلاةٍ فيه، كما قام جلالةُ الملك خالد - كحمه الله-بالتبرع لأُسر شهداء الحرم بمبلغ اثني عشر مليون ريال.6

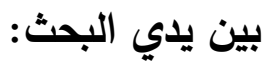
ارتجت لصيحات البيت الحرام قلوبُ المسلمين، ودوَّت جُثث الضحايا في أعماق نفوسهح، فسطرّروها في ذاكرة

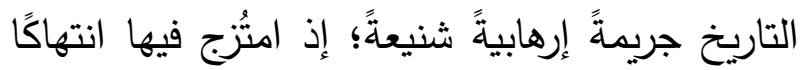
حرمة الزمان بالمكان بدم المسلم، وشكَّلت هُنعطفًا خطيرًا أثَّزّ على الحياة الدينية والفكريَّة والثقافيّة والسياسية والاجتماعية في المجتمع. وفيما يأتي قراءة مشهدٍ شِعريٍّ سُطِّرَ بحُرقةٍة في تلكِ

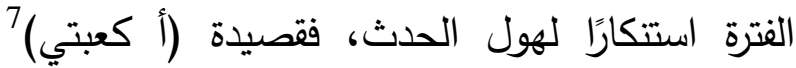
للشاعر عباس بن محمد بن غالب الثَّريف 8 -رحمه

‘2،7\%D9\%8A\%D9\%85\%D8\%A7\%D9\%86 أغسطس، 2020م؛ و انظر: https://www.bbc.com/arabic/middleeast50924634، 2، أغسطس، 2020م. 7 القصيدة غير معنونة، وقد أطلقت عليها (أ كعبتي) بأولَّ مفردة في

القصيدة.

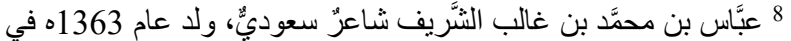

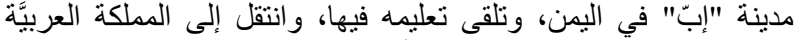

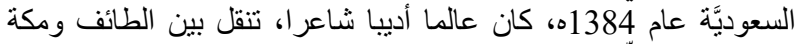

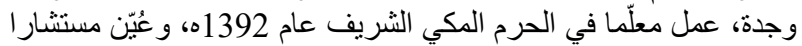

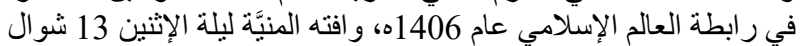

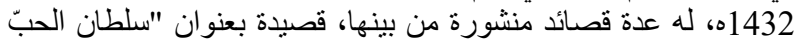

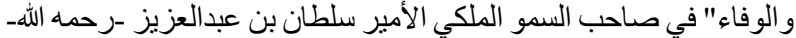

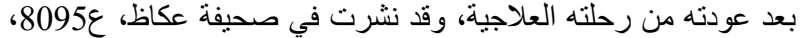
في 6 سبتمبر 1988م، ومن أبياتها:
الله الحرام وفي شهره الحرام، في الوقت الذي لم تتوفر فيه الإمكانات اللازمة للقضاء عليهم. ولأنَّه لا يحل القتال في الثهر الحرام والبيت الحرام جاءت الفتوى الدينية بجواز استخدام السلاح في الحرم والقتال فيه حماية لأرواح المسلمين من أسنر القوة الباغية، فاستعانت المملكة العربية السعوديَّة بفرنسا، فأرسلت العن العاعيه الأخيرة إليها ثلاثة خبراء من وحدة مكافحة الإرهاب،

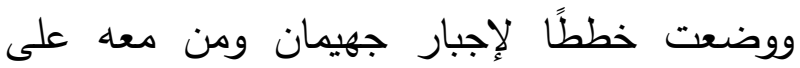
الخروج من مخابئهم في الحرم والاستسلام، وإطلاق سراح المحتجزين، فتم ذلك يوم الثلاثاء 14 محرم الموافق 4 ديسمبر 1979 م، بعد حصار الجماعة الإرهابية للمسلمين أربعة عشر يومًا في أقدس بقعةٍ على وجه الأرض، حُرم المسلمون فيها من الصلاة والطواف وسماع الأذان، وزاد على ذلك أن مُلئت

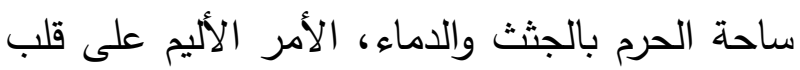
الأمة.وقد أسفرت هذه الفاجعة عن مقتل سبعٍ وعشرين

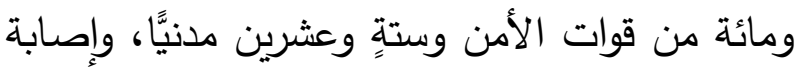

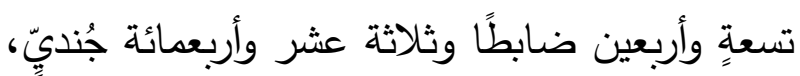

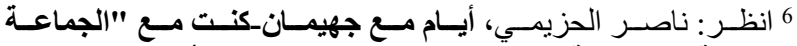

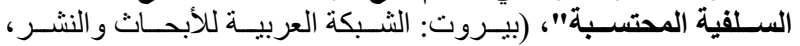

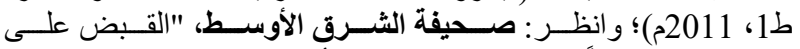

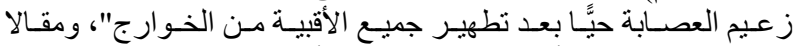

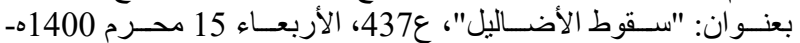

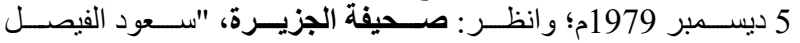

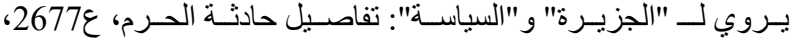

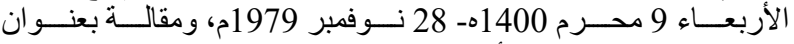

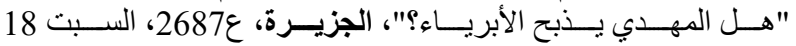

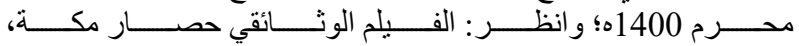
https://www.youtube.com/watch?v=hXDQSsLx8q

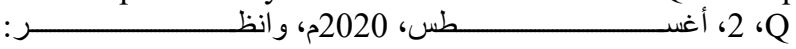
https://www.bbc.com/arabic/resources/idt2sh/idea_arabic https://alwatannews.net/search/\%D8\%AC\%D9\%8 
بتكثيف وصف البيت الحرام وما يتعلق بحرمته، والفئة الضالة وبشاعة الجرم. وما شدَّ من أزر ذي الحجج وغيرها تكريس تقنيات الحجاج اللغوية التركيبية في النص، كما سيرد ذكرها في صفحات البحث. ثانيًا : حجج الاثتراك: هي قواسم مشتركة، وقيم بين المخاطِب والمخاطَب يلوذ بها الخطاب للإقناع والاستجابة الفعليَّة له 10، وفيها تُستثر المسلَّمات والثوابت الدينيَّة والأخلاقيَّة والفكريَّة 11. ومن المسلمات الدينيَّة والقيمة العليا المشتركة للمسلمين قدسيَّة الكعبة واحترامها، وربَّما يعرف عن هذه القداسة غير المسلمين؛ لثدَّة تعظيم

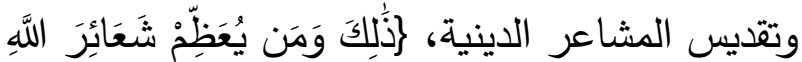

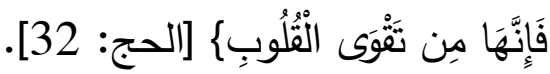
فالمشترك الديني هنا أقوى تأثيرا وأعمق، يضاف إليه حرمة الدّماء، والأعراض، والثَّهر الحرام، والبلد الحرام، والبيت الحرام، وهذا يداعي إلى الذهن أيضا قيمة عليا مشتركة، كعدم جواز ترويع المسلم لأخيه المسلم، وترويع الطير والحمام كذلك. وكلها تنتظ سلسلةً من البراهين الحججيَّة على جرم الإرهاب، ومن الأبيات التي تضمنت تلك الحجج على سبيل المثال لا الحصر : البيت رقم 2-6-7-13-15-33.12

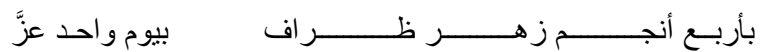

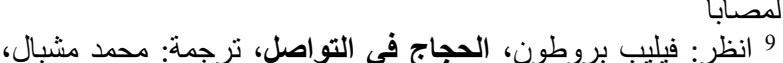

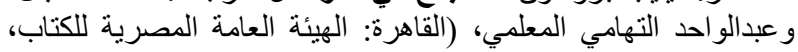

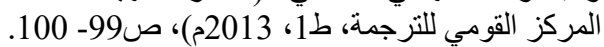

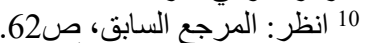

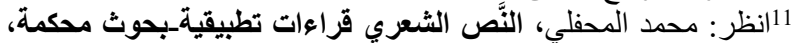
"شعرية الخطاب الحجاجي في ديوان البهلاني"، (بيروت: الانتشار

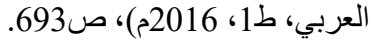
12 القصيدة موجودة في ملحق في آخر البحث.
الله- التي كتبها في (9-1- 1400هـ) تقطر حزنًا وأسى، ومطلعها:

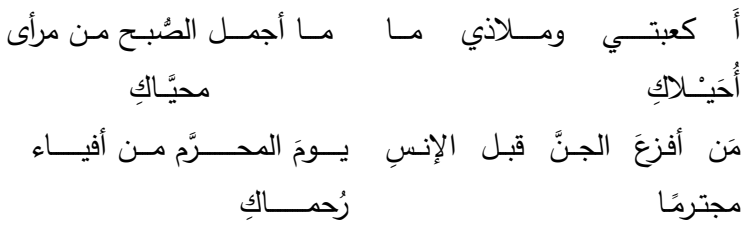
شعريَّة الأسلوب الحِجاجي في النَّص يتمثل في: أوََلًَ: حجاجيَّة السُّلطة: والسلطة هنا قوامها الدين الإسلامي بتعظيمه وشعائره، وهي سلطة لها احترامها ومكانتها، تقطن عميق روح المسلم وتروي فؤاده فتنطق بسلطته الخارجيَّة طاقةً محرّكةً له للانطلاق في بناء الكون بإيجابيَّة وسموّ فكلّ ما يتعلق بالدين حجة بذاته، وكلّ ما يحاول مساسه بسوء يتعرض للهجوم السحيق والعقاب الأليم، وهذا ما حدث في النَّص. فقوام النَّص وزوَّادته حجج سلطويَّة دينيَّة أصيلة وراسخة، صريحة وضمنيَّة، تُرصّع فضاءه وحشاشته، مستميلة عاطفة المسلمين في أنحاء المعدورة، ومقيمة الدعوى والحجة على الباغي الخائن. وهذه الحجج المرصّعة النَّص أطلق عليها حجج التأطير التي تعمل على توشية الخطاب بالحجج من الداخل 9، وقد اشتمل النص على ذلك

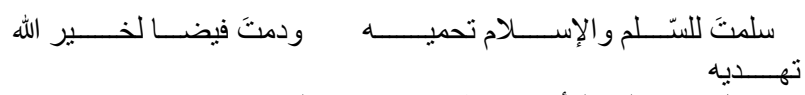

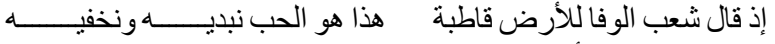

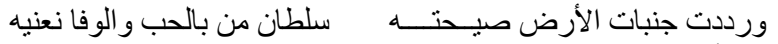

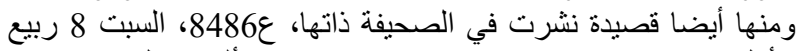

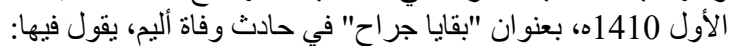

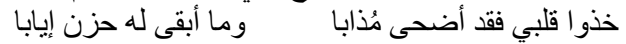

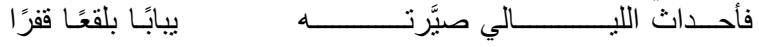
خرابــا فـا 
وهذه الحجاجيَّة قائمة على التحاوريَّة بين مخاطِب ومجموعة مخاطَبين:

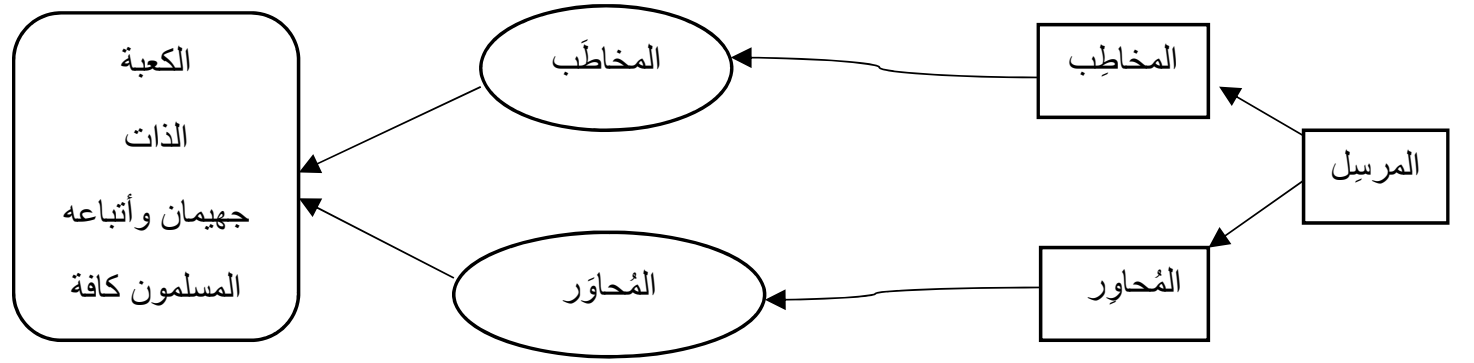

ثالثًا: حجاجيّة الأساليب الإنشائية

فالنّدِاء والتساؤل في فاتحة النص تغزُّل بالحبيبة في ظاهر الدلالة وفي المقابل حجةٌ على الخصح في النَّصِّ المكبوت: (هل حقَّا ما حدث؟ لماذا؟ كيف تجرَّأ). ثم ما يلبث أن يتفتق النص عن مكبوتاته

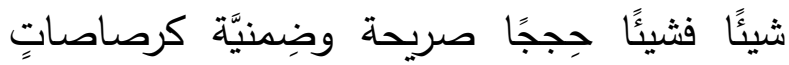
متدافعة عبر بنياتٍ من الدَّوال الإنشائيَّة في الأبيات الخمسة في المطلع:
نغمة النص الانفعالية مرتفعةٌ منذ أول حضورٍ دلالي للإنشاء المتكئ على تقنية الحوار (أَ كعبتي)، ذلك الحضور المزدوج ما بين النِّداء والاستفهاميّة، فوقعُ الصدمةِ على المُبدع أحدثَ في داخله فجوة توتُّر متذبذبة تآخت فيها دِلالتان في حميميّة حوارٍ مع الحبيبة المغدور بها بنداءٍ غزليّ لطيفٍ شفاف (أَ كعبتي) الجميلة مُستقرَّ راحتي التي تضفي على الكونِ إشراقًا ونورًا، وتساؤل في ذات الوقت : هل حقًا ما حلَّ بكَ

\begin{tabular}{|c|c|c|}
\hline الحجة & مقولة البيت الثعري & 5 \\
\hline 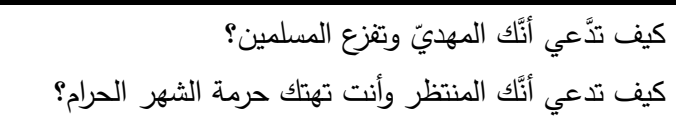 & من + أفزع الجنَ قبل الإنسِ مُجترمًا يوم المحرج؟ & 1 \\
\hline كيف تدّعي المهديَّة وتروّع قلوب المسلمين؟ & مَنْ + أبدلَ العينَ سُهدًا لا نظير له؟ & 2 \\
\hline ألا تعلم أنَّ الله وجَّه القبلة في رحلة عظيمة إلى أقس مكان؟! & مَن + أفزع الوفُفْ في علياء مسرالكِ؟ & 3 \\
\hline كيف تدعي الإيمان وقد انتهكت حرمة البلد الحرام؟! & هل + كانَ ذلك حُلمًا قد طُرقتُ به؟ & 4 \\
\hline برّرت لنفسك تحليل الأمر لغرض آخر في نفسك؟! & أم أنَّهَ الحقد لم يترك لصاحبه من خوف ذي العرش؟ & 5 \\
\hline
\end{tabular}

فالطاقة اللغوية المستمدة من دوالّ الاستفهام "مَنْ" أضفت على النّص حيويّةً تركيبًا وإيقاعًا مُوشّاة بتردادها، و "هل" المتازرة مع الطاقة التعبيرية الصوتيّة بمغرداتِ الخوف والفزع. المستمدة حِجاجيتها من المقام ومقتضى حال المبدع 
يُظهر النص حذقًا في استخدام أوراق من أروقة التاريخ المتَّمة بالصدقيّة، فاتكاء الخطاب على وقائحَ تاريخيَّة

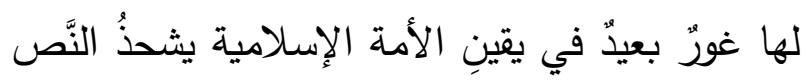
بطاقةٍ حجاجيّةٍة لها ثقلها في رفد دلالته الكليَّة. فمنذ الأن بدء الخليقة كسا المولى -عز وجل-الكعبة الشريفة

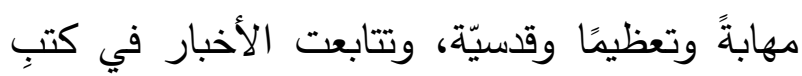
التاريخ سردًا بالنقل والتواتر عن بناء الملائكة -عليهم

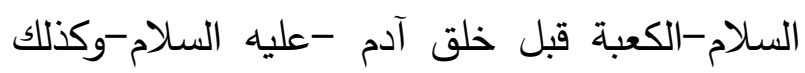
البيت المعمور، وكيفية بناء آدم -عليه السلامللكعبةِ، ثم ما قام به إبراهيم وولده إسماعيل -عليهما السلام-من رفع دعائم البيت وبنائهِ بعد أن أصابهُ

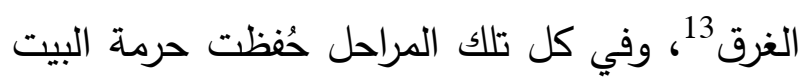
الحرام، ثم ما تلاه في تاريخ السيرة النبوية من تقديسٍ له عند قريش ومن تحويل القبلةِ ورحلة الإسراء المباركة.

فالسياقات التاريخيّة المتتابعة رفدت النص ببراهين وإثباتات جوهريّة لا يمكن نُكرانها في وعي التاريخ، وكل هذه الأحداث التاريخية اختُلت في قول الثاعر :
وتذبذب رُوع المبدع بين الغزل والهلع المصحوبين بالإنكار وجَّه التراكيب النصيّة نحو التوتر في بنائها

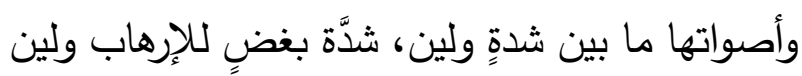

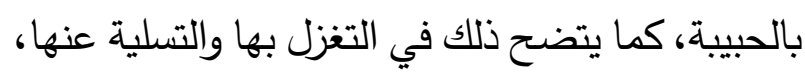
وبرويّ الكاف المكسورِّ الناجمة عن كسرٍ في صميحِ الثاعر وجوفها. فالفاتحة النصِّية طاقةٌ حركيّة مُشتعلة مُتنامية نحو الإنكار والرفض بأقوى الحجج (الكعبة -الجن قبل

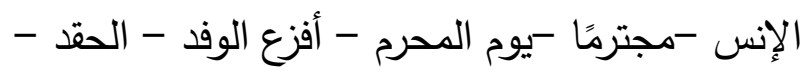
الإرهاب - ما يكفي لتقواك). ويتكرر النداء في النسيج

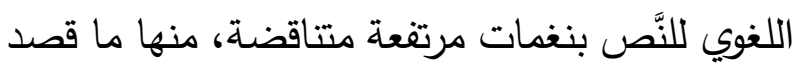

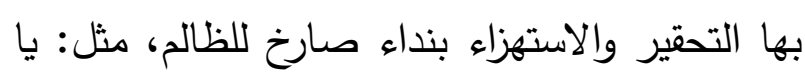
فتتة الجهل والتهويس، ومنها ما كان نداءً من قلب دامٍ على الكعبة، مثل: يا كعبة الله هل حلمّ بليت به. 
صنع كنيسة (القُلَّيس) في اليمن وأراد هدم الكعبة لينصرف الناسُ عنها إلى الكنيسة، ولكنّ الله -جلَّ جلالهه-منعه بالطَّير الأبابيل.

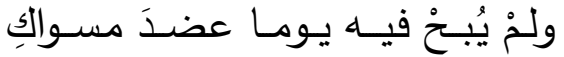

$$
\begin{aligned}
& \text { طيــرا ليحصــــــالتـدقيـق أعــالكِ }
\end{aligned}
$$

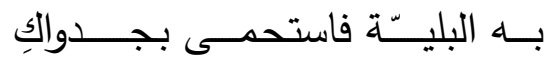

$$
\begin{aligned}
& \text { لكتّا تهـــــاوى إلـى عليـــــاء يُمنـــــالكِ }
\end{aligned}
$$

إلا هلاكك وهلاك قومك، إنَّ هذا بيثُ الله الحرام، ولم

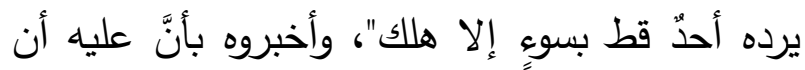

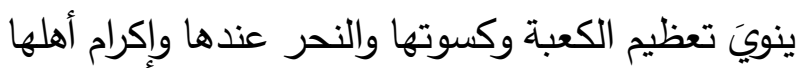
ليُصرف عنه السوء ففعل، وانجلت عنه الظلمة، فظلّ مدة إقامته في مكة ينحر كلّ يومٍ مائة بدنة يُكرم بها أهل مكة ولم يتتاول منها شينًا هو وقومه، وكسى البيت

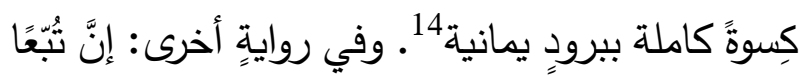
عندما عزم على هذْمِ الكعبة عُوقِب بداءٍٍ شديدٍ في

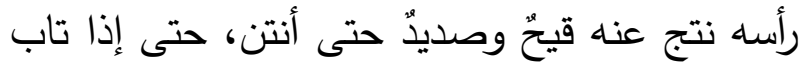

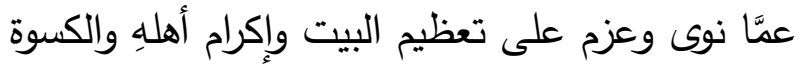

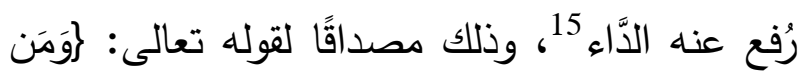

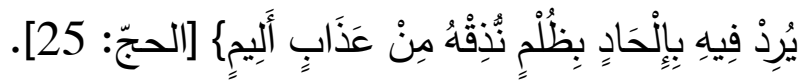

ثم يسرد النَّص نوعًا آخر من الأحداث التي آلمت وعي التاريخ وخلّدت بين دفتيه سلسلةً من الجرائم

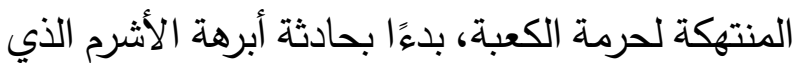
يقول الثاعر في توالي التَّريخ الأليم:

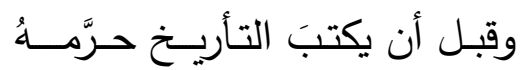

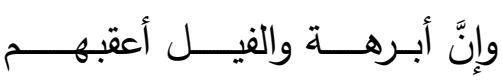

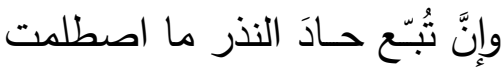

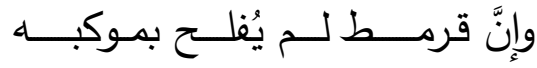

وفيما يُروى من الأخبار أن ثلاثةً من التَّابعة من ملوك اليمن حاولوا تدمير الكعبة ولكنّ الله بالغُ أمره وحامٍ

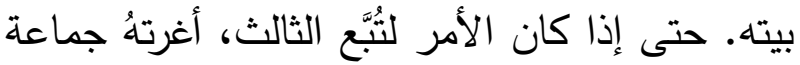

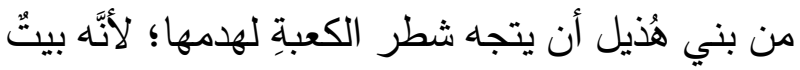
تُعظّمه العرب وتتحر عنده، وحازت قريشٌ شرفًا عاليًا لخدمتها له، وكان الأولى أن ينال هو هذه الدكانة، فلو أزال الكعبة وبنى عنده بيتًا وحج الناس إليه نال هو الثرف. فعقد العزم على السير إلى الكعبة وتتفيذ

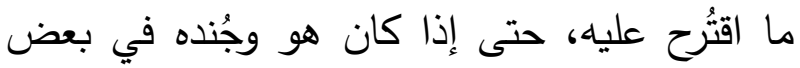

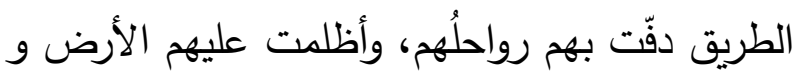

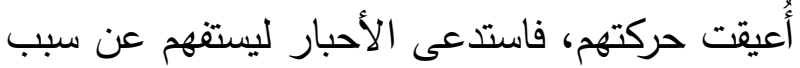
ذلك، فسأله الأحبار عن نيّتهِ الصادقة نحو هذا البيت،

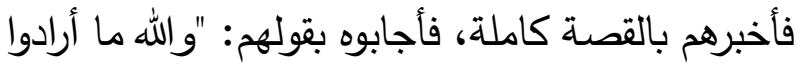

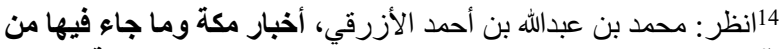

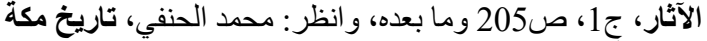
المشرفة و المسجد الحرام، ص276-77. بطه.
} 
وخلعوا باب البيت، وصعد أحدهم ليقلع الميزاب ولكنه

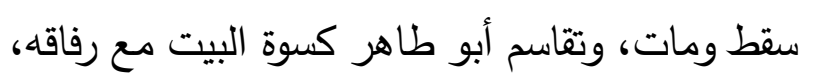

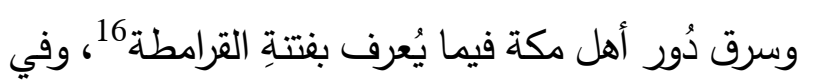

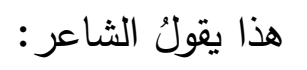

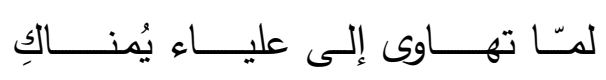
وقد اختُزلت نتيجة كل الجرائم ضد الكعبة في الثطر الثاني من البيت:

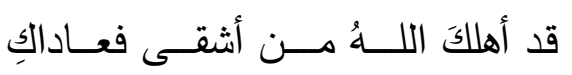

وما زال التاريخ يُعيد كرته ويتجدّد، ففي عام 317 هـ

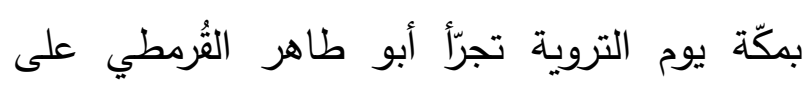

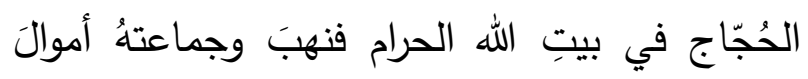
الحجاج وقتلوهم ورموا الجثث في بئرِ زمزم ودُفِنَ البقية في المسجد الحرام، واقتلعوا الحجر الأسود من مكانه

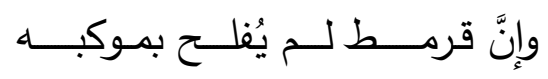

الدلاليّة لمفرداتٍ مُندغمةٍ معها ترادفًا، وأهم هذه الحقول: - (لاله

\section{أ- حقلُ الخوف:}

تثظتَّت دوال هذا الحقل أبعادًا دلاليّة في أعطافِ

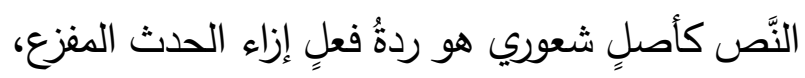

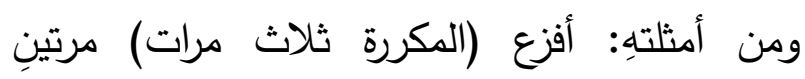

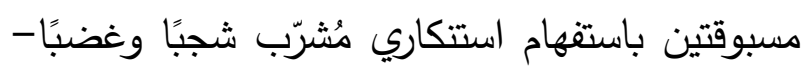

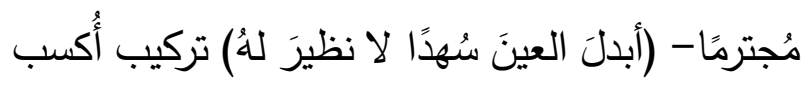

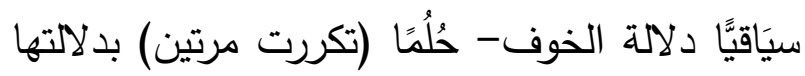
العميقة على الذهول والتهرُب من وعي الحقيقة ودلالتها الضِديّة في النصِّ المتواري الراجي أن يكونَ ولَّن

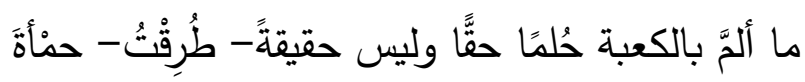

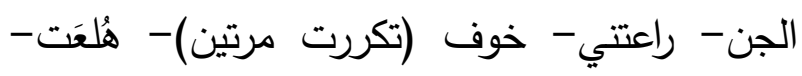

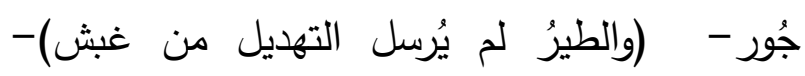

فتداعي السياق التاريخي سردًا في نسق الهجوم

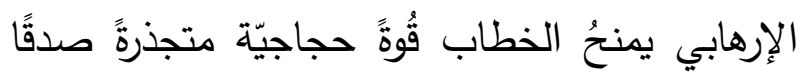
وأثثرًا، والمتلقي أُذنَا مُصغية واعية تقرأُ حلقاتهِ سطرًا سطرًا في عُمتي مخزُونها الدّامي، وكأنَّها تُشاهدهاه

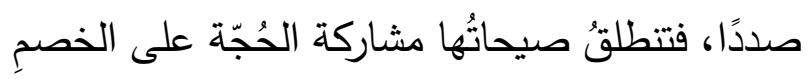

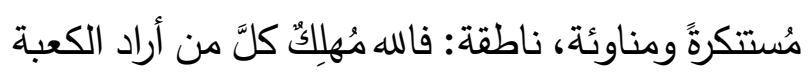

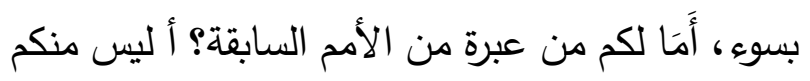

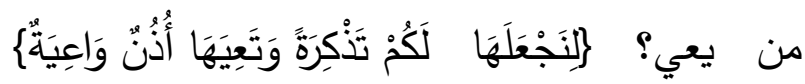
[الحاقة: 12].

\section{خامسًا: حجاجيّة الحقول الدلاليّة} يعجُ نسيجُ النص بدوالِّ شعوريَّة تدورُ حول أفلاكٍ

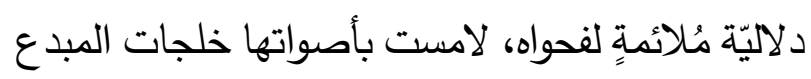
فالمتلقي، وامتزجت روحها بصدق الألم وهول المصاب. والحقلُ الدّلالي هو شبكة من الوشائج 
يخدم الآخر في محور (الإرهاب) توافقًا وتضادًّا. وهذا

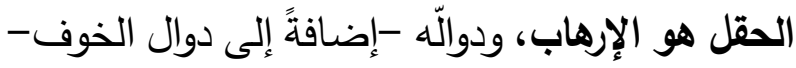

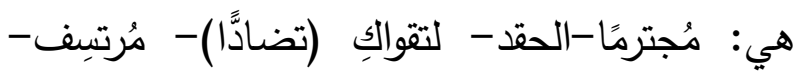
أفَّاك- أثقىى - عاداكئ- فتتة الجهل والتهويس - أيديهخ الحمر - شرعة الغاب- خطب- (داس الأعادي حرمتيه)- (ديسَا غضاضةًً)- مُجرم- القتل - شائن -

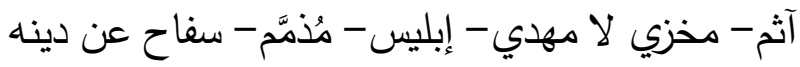

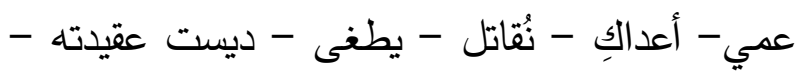

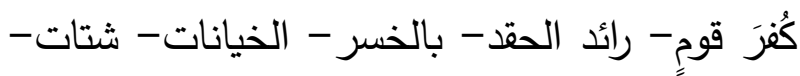
إثمات - مزرعةٌ للشر - زمرةٌ باءت بلعناتِ- مُفنتئُ

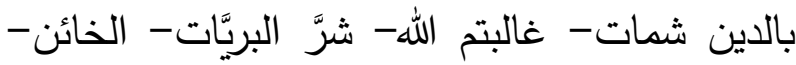
العاتي. فاكتظاظ البنيات اللغويّة في الخطاب بدوال الإرهاب ومدلولاته السياقية يتمخض عن قوةٍ حجاجية في دحضه جلائيّةً في التنفير منه ومن أصحابه. سادسًا: حِجاجيّة حقل الزّريف اللوني هذا الحقل نشرة نفسيَّة لدواخل الذات المرسلة وللنَّص والمتلقي تضامئنًا وأثرا، والرَّديفت اللونيّ هنا اكتسب حجاجيّته من النِّياق المذاب فيه في نسيج النَّص، فالقصيدة ليست لونيَّة في بُنيتها الظاهرة إلا من اللون الأبيض والأحمر المذكورين صراحةً (مرة واحدة)، وماعدا ذلك فالألوانُ تتوارى خلف ملبُوساتٍ رديفة

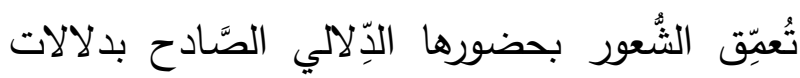
الحوار المتفاقمة ضد الإرهاب الذي رُمّز للهُ باللونِ الأسود النابع من ألفاظ الخوف والإجرام المنتهكِ البياض والسلام والأمن الرامز إلى الكعبة، فبين الخيرِ

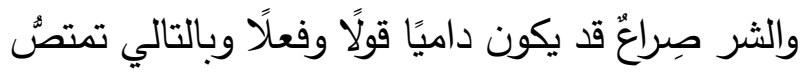

رصاصاتُ بأحشالكِ- (نبشت أيديهم الحمر من قبرٍ

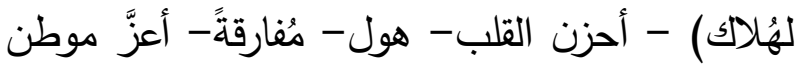
أمن- (هاجر الطير)- (الموت يسقى في زواياك)-

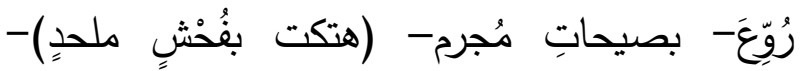

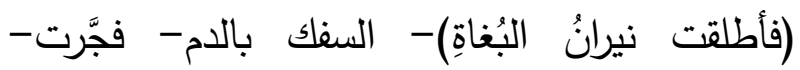
فجيعة- الطاعون- الرصاص. فمن اللافت للنظر تناثُر الخطاب بَألفاظ الرُّعبٍ والهلع الجليَّةِ حُضورًا والمبتغاة غيابًا في باطن الدلالة، والدكسبة بنيات النص التركيبية ذاتَ الدلالة المذابة فيها سياقيَّا.

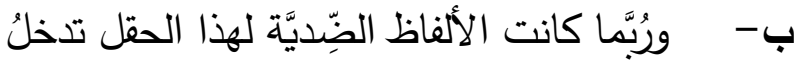

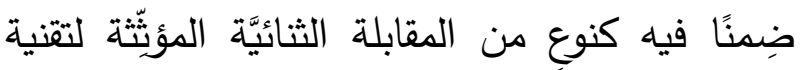
الحِجاج الصَّريح والضِّمنيّ في النص؛ إذْ بالإضافة

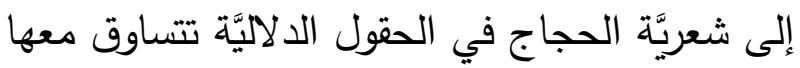
شاعريَّة الثنائيات المتضادة لتمنح الحجج صرامةً وقوةً

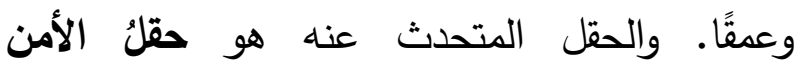
والطمأنينة وتتدرج تحته المفردات الآتية: ملاذي- واته الأمن (تكررت ست مرات اسمًا، ومرةً بصيغةِ الفعل

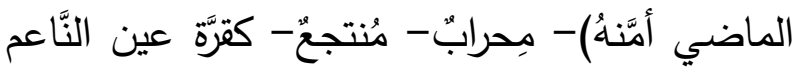

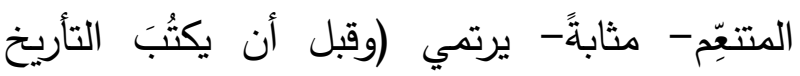

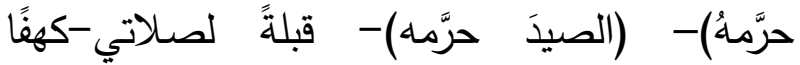

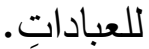
ومِنَ الملاحظ أنَّ دوال الفزع والخوف أكثرُ من الأمن وهذا يعكس صدمة الخطاب من جهة واستنكاره ودحضه من جهة أخرى. ج- وقريبّ جدًا من هذين الحقلين وربمّا امتُزج مع مدلولاتهما السياقيَّة ودوالهما إلى حدّ كبير إذ جميعهم 
صراعاتِه وحججَه ردائُعُهُ اللونيَّة؛ إذ تكتسب الدَّالات نحوها. والبياض هنا في باطن دالة السَّواد، ويتجلّى

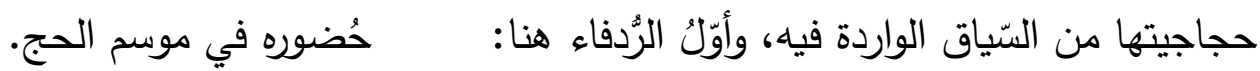

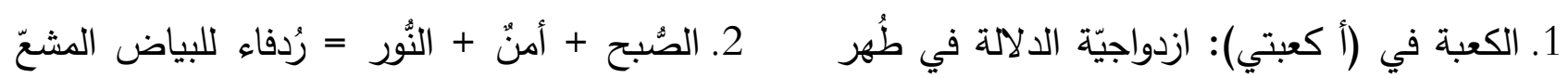

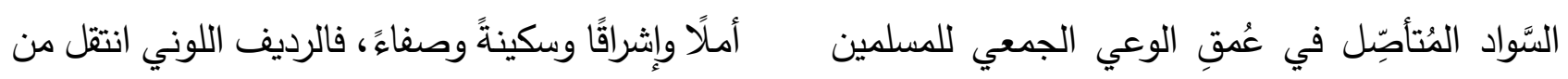
"- البياض

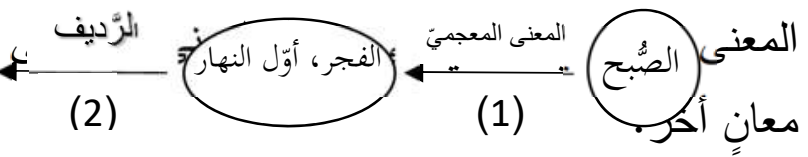
مع بياض السكينة فيه والأمن، وأرواح الميمِيّين

5- الجنّ + حمأة الجن = رديف للون الأسود الدال على سواد الثَّر ومنه إلى (الفئة الباغية)، وربَّما دالَّة (الجن) أفضت باللون الأحمر الدَّال على الدمويَّة

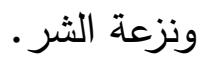
6- الحقد + جور + رصاصات+ ظلماء = دوالٌّ تُفضي إلى دلالات الظلام ومنه إلى السَّواد ومنه إلى جلى تلى

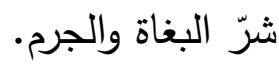
7- الموت + الدم= المتجهان صوب اللون الأحمر النازع للشرِّ والقتلِ والهلالك وإيماءً بالجُثث. 8- راعتني تدل على الخوف ومنه إلى السواد ومنه ولهـ

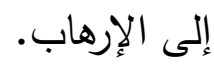
9- غبش 17 = تدل على كدرة البياض مع السواد.

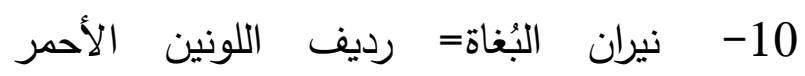
والأصفر
إذًا : الََّّالَّة= المدلول الأوَّل + المدلول الثاني (الرَّديف)=

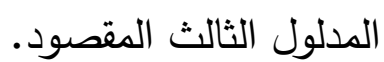
إذًا: اللَّالة= الأمل والطُّهر والصفاء والأمن والنَّكينة.

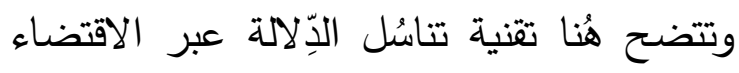
الدلالي للتوصل إلى مدلول الرديف، وهكذا في بقية الدَّالات الرَّديفة. 3- علياءَ مسرالكِ: المقصود بها السَّماء الواشية بزرقتها وبياضها، والرَّامية إلى معنى الصفاء والنقاء والثفافية والسلام. 4- الطير: ربَّما قادنا الطيرُ إلى عدة ألوان ولكن اتساقًا مع نسق النص واتحادًا لتوجيهه الدلالي؛ فإنَّ

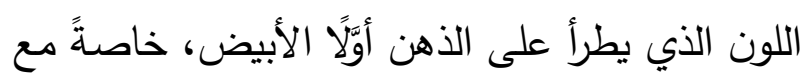

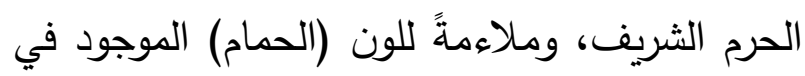

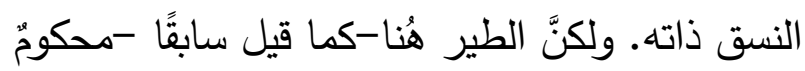

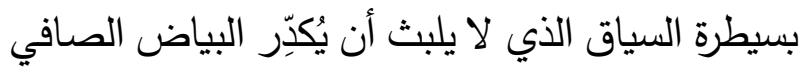

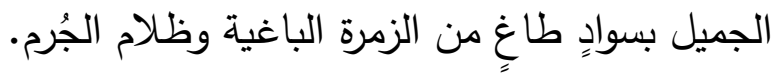

17 الغبش: بقية الظلمة يخالطها بياض الفجر : محمد بن مكرم بن منظور ، مادر،

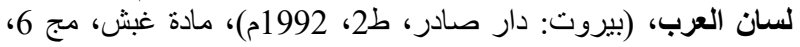

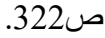


ترنَّحت بين البسيط فالطويل ثم عادت مرةً أخرى إلى الى

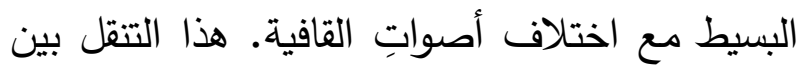
البحور ما هو إلا دليلٌ على القفزاتِ الانفعالية لروح

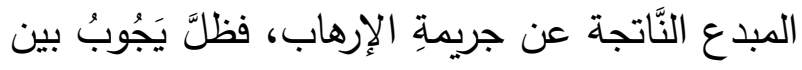

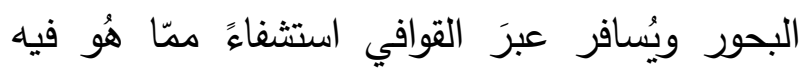
ومتلمِّسًا بتتقلاته تفريخ شحناته الحانقة على الواقِعِة الذَّميمة، وفرارًا من التَّصديق بها.

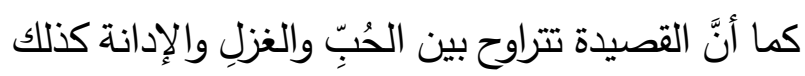
إيقاعاتها وأصواتُ قوافيها تمورُ مورًا بين حالتَّي العُلو والانخفاض، بين الانفعالِ المنتِقِّد ومُحاولة التهدئة

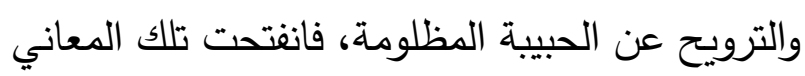

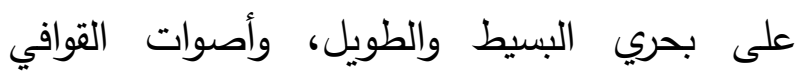
المتحركة بالكسر (الكاف والميم والتاء)، لتُخذيَ ولئي الخطاب بالأبعاد الدلاليَّة الملائمة لنسقه، وتُسهر معأُ في رسمِ آفاقٍ بعيدةٍ المدى من المتواري خلفهُ. أمَّا القوافي فهي أصوات اتَّددت في صفة الثَِّّة مُوحية

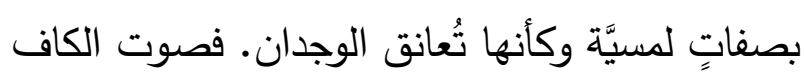
ممتلُّ في النّطقِ، ومع الكسرِ يُومئ بالحرارة والقوة

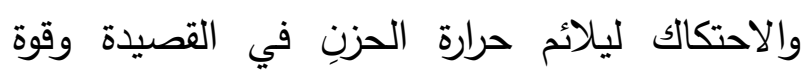

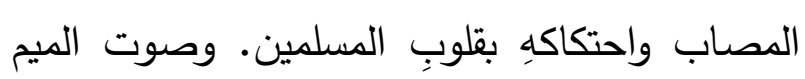

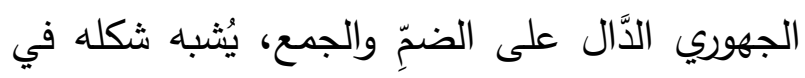

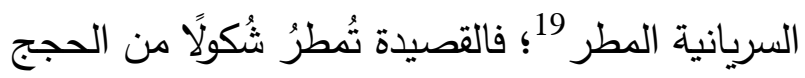
ومواثيق الحُب، وتوحي باجتماع الأمة واتحادها في

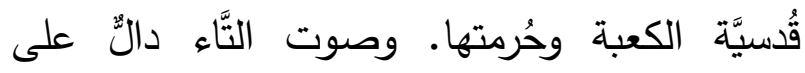

19 انظر : حسن عباس، خصائص الحروف العربيَّة ومعانيها، (دمشق:

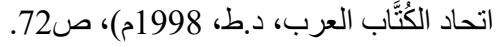

ودوران النَّص حول هذهِ الألوان الحربية يُشير إلى الكى الحرب السَّرمديَّة بين النُّر والظلمة والخير والثران الثر مهما صدر عنها من قتلٍ لأرواح الأبرياء وسفك الدماء. سابعًا: حجاجيّة البنية الإيقاعيَّة الإيقاع هو السمفونية الوجدانية التي يتردد صداها

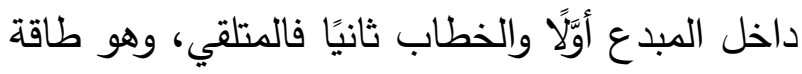
مؤثثةُّ للنَّص صوتًاً ودلالةً عبر بنياته اللغوية، تكرارًا

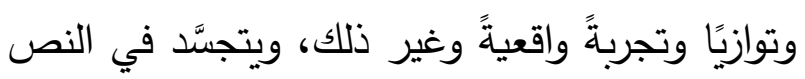
خارجيَّا وداخليَّا.

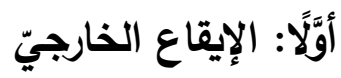
تُطرِب الموسيقى زوايا النص الثعري فينتشي بها المتلقي وتتسرب ظلالها الدلالية في رُوحه صدئً يُشارك به المبدع في انفعالاته وصدْقِ شعوره محبةً

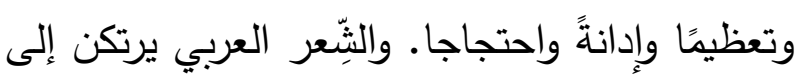

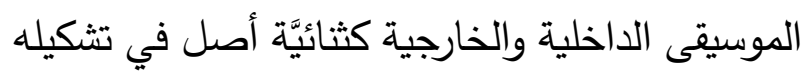
الموسيقي 18 . والأبيات الحزينة من بحر الطويل وهو من البحور ذات النَّنس الطويل التي يبسُط فيها الثاعر لفئر

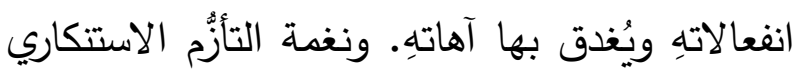

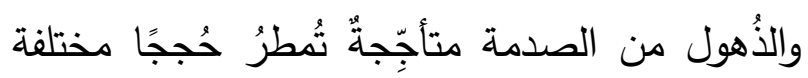

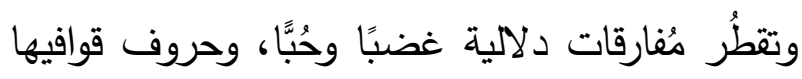

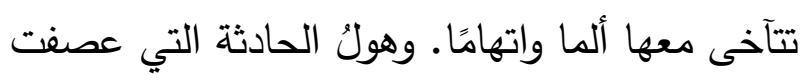

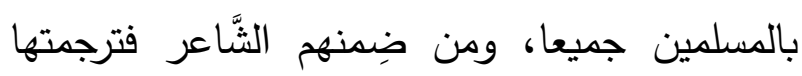

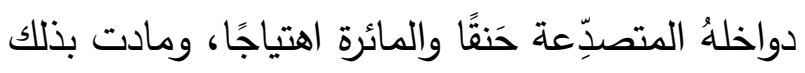

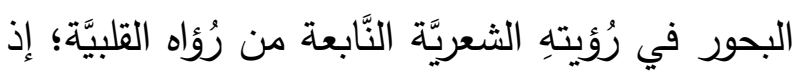

18 انظر: نهيل فتحي أحمد كتانة، دراسة أسلوبية في شعر أبي فراس الاس الجاس

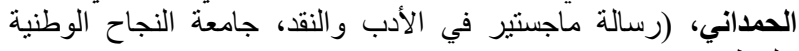

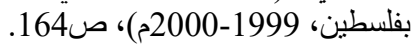


الاضطراب، ذو همٍٍ مرصّعٍ الأبيات بالانفجار 1. التَّكرار: يسعى النص الثعري إلى أن يكونَ مُقنعًا

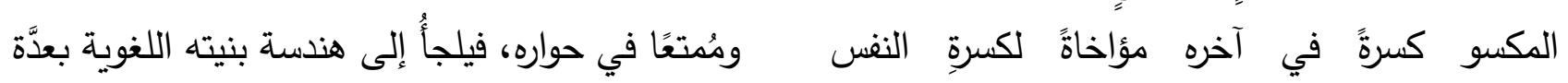

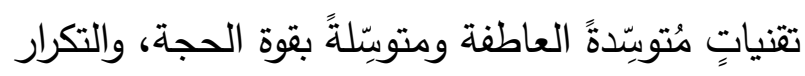
المضطربة.

إحدى تلك التقنيات المؤثرة في إيصال الرسالة المتغياة للمتلقي وقد امتزجت بمشاعره. ومن صُور التَّكرار

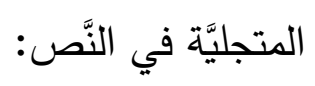
أ. تكرار الحركة والحرف: فحركة التتوين في قولِ الثاعر :

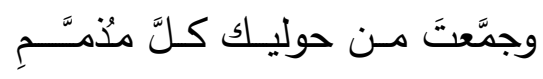

رُحمالكِ- مسرالكِ- أمن ومحراب ومنتجع - كعبة اللهأعزّ موطن أمن - الحطيم وزمزم- حرمتيه- محلة تكريم- البيت العتيق. وتكرار مدلول الإنهانة

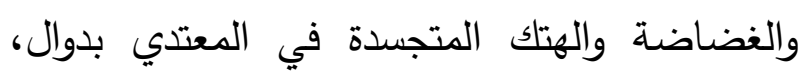

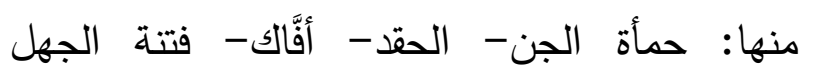

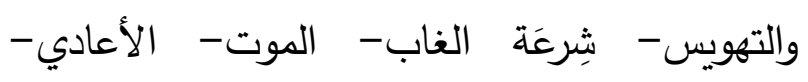

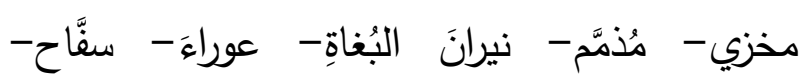
الطَّاعون.

فسرد الدَّالات بمدلولاتها بذاتها وبمثيلاتها الواصفةِ لها

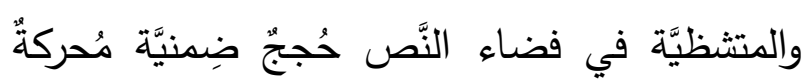
لوجدان المتلقي استمالةً وإدراكًا، وباعثةً لهُ نحو الإقرار بعِظَم الحدث ومن ثمَّ تأييد النتيجة والحكم على العاتي. 2. السَّجْع: ومُوسيقاه العالية الرنَّانة مطربةٌ النَّص والمتلقي، جاذبةٌ لتلافيفها، وذلك في مطلع القصيدة: مـا أجمل الصُّبـح مــن مرأى محيَّالكِ

طغت على البيتِ كطُغيانِ الآثم، وكان أنْ تكرَّر ذا

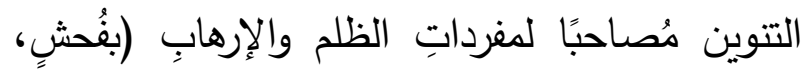

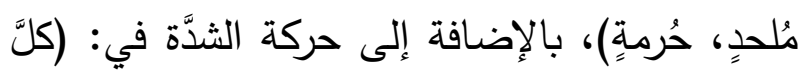

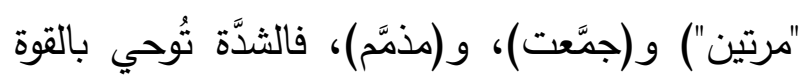
والعمق واقترانها بحرف الميم المكرَّر ثمانِي مراتٍ

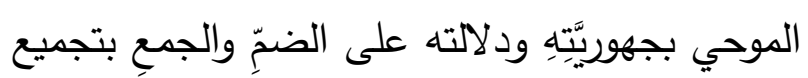

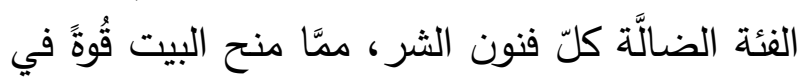

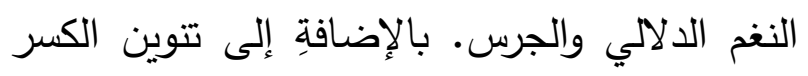
المكرَّر ثلاث مرات مع حرف الحاء القاطنة في الثلاث كلمات المنونة أضفى ركازةً وحفرًا للالالة مع ترنيمته. ب.تكرار دالات متضادة ومدلولات: كتكرار مدلول التَّعظيم والحرمة المتجسدة في دالَّة

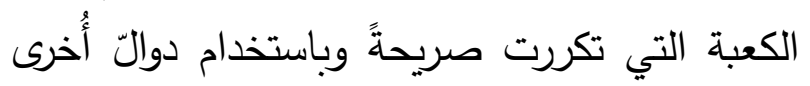
صادحة بدلالتها، مثل: الكعبة- ملاذي- أفياء

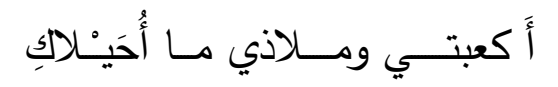


فبين أُحيلاكي ومُحيالكِ سجعٌ مع تكرارٍ - في البيت -لافت للحروفِ ذاتها (الحاء والياء) المشعَّة نغمًا عاليا. ويتكرَّر

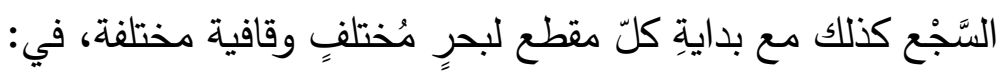

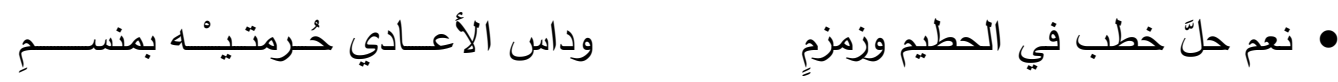

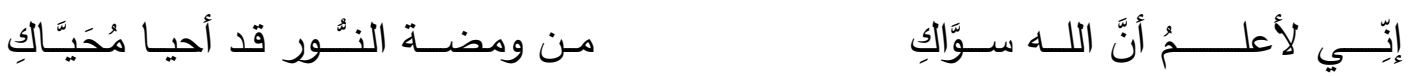

3. الجِنَاس: بين الدَّوال جناسُ ناقص، نحو: لغوٌ ولغط، وجناس تام مطرب بين (محرًَّا والمحرَّم)، في:

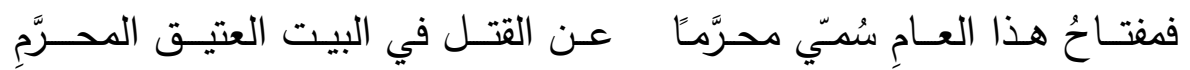

فالأول وسْمُ لأول شهور السنة الهجرية والثاني صفة للبيت الحرام.

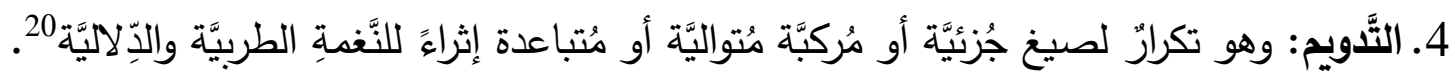

وقد ورد في نسيج البُنية النصيّة ما يأتي:

1. "الله أكبر" تكررت ثلاث مرات مُتباعدة مُقترنة بموقفٍ صاخب من نُكران الجريمة وانفعال مُتِّتِدِ من الحزن.

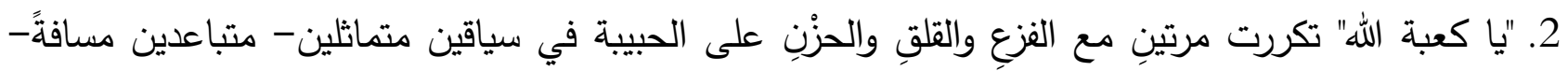
تلتهما أداة الاستفهام (هل) المستنكرة.

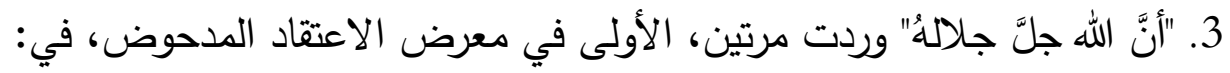

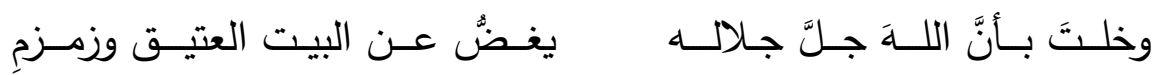
والثَّانية في الإجابة القاطعة:

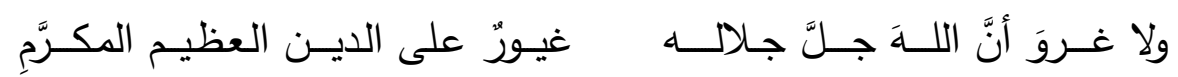

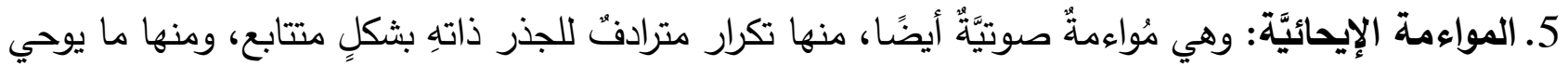

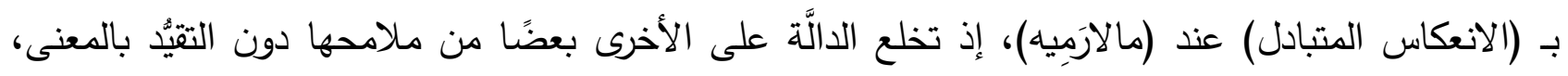

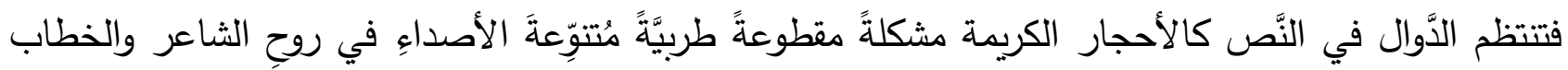

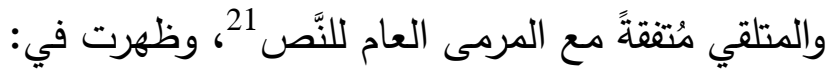

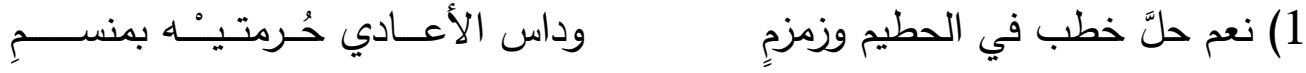

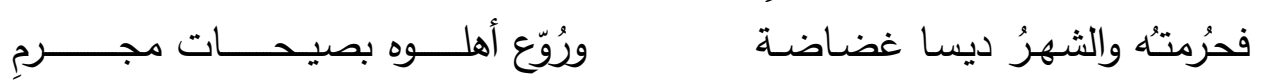

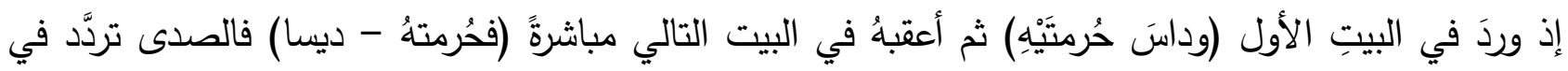
بيتين متواليين.

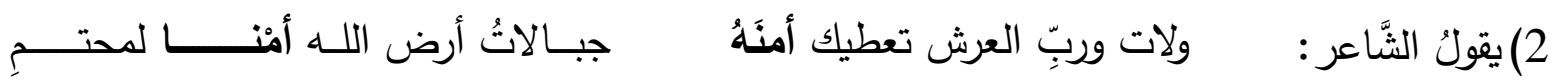


المواءمة الصوتيَّة بين أمنه وأمنًا.

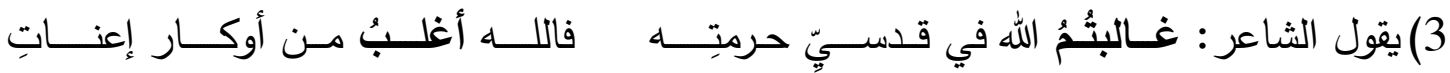

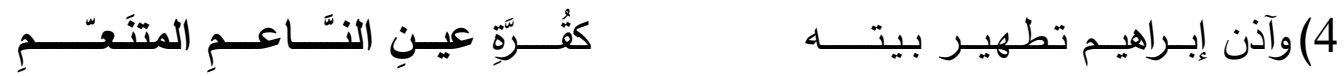
مواءمة إيحائية متداعية الملامح مع تكرار العين والنون.

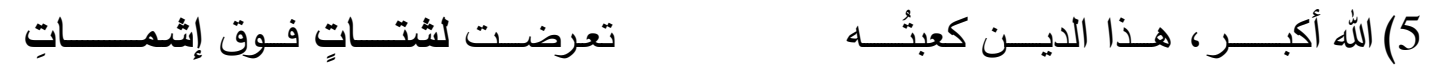

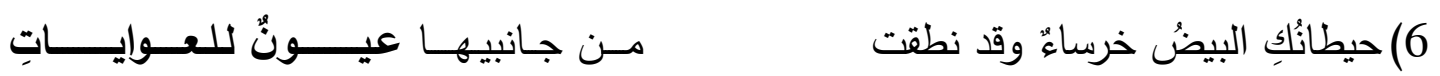

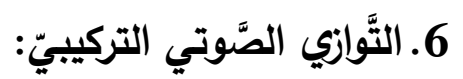

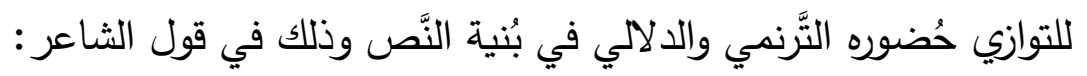
أ- مُنزَّهـةُ الأركـان من كلِّ شائسنِ

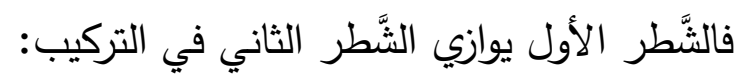

اسم مفعول+ (مضاف إليه مجرور )+ منْ كلّ + اسم فاعل اسم مفعول+ (جار ومجرور )+ منْ كلّ + اسم فاعل وهذا ما يكسب النَّص طلاوة وترنما.

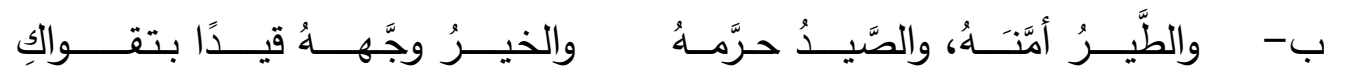

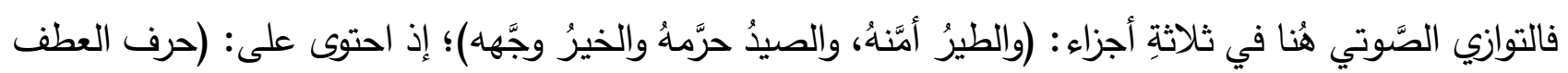
الواو +اسم +فعل ماضٍِ مُشدَّد).

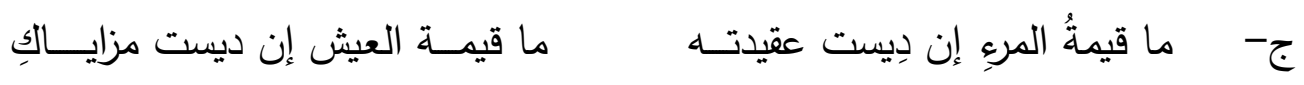

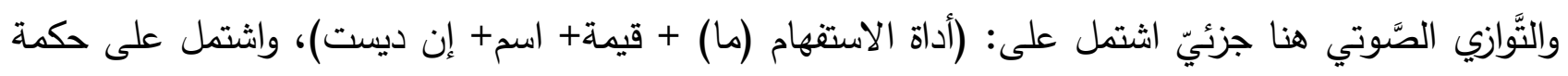

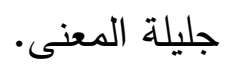
ثامنًا: حجاجيَّة بنية التراكيب اللغويَّة:

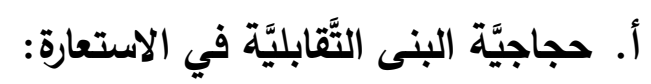

من جُملةِ المعنى ومعنى المعنى والمعاني المتناسلة

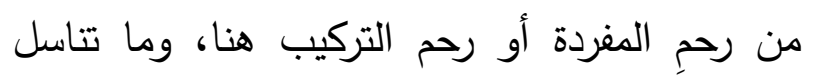

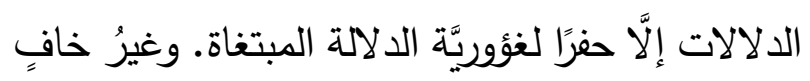

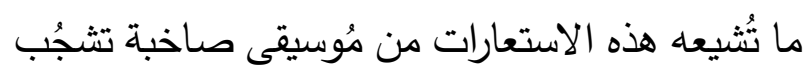
وتُنكر وتهدهد في آنٍ معًا.

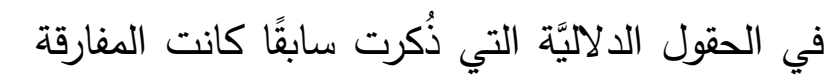
فيها بادية للعيان في المفردة، وفيما يبدو أنَّ القصيدة

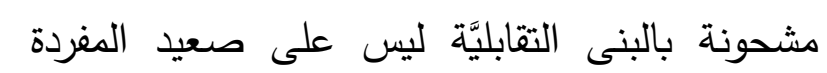

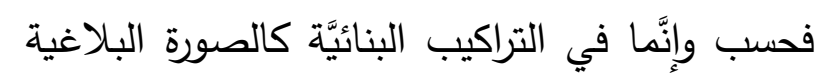

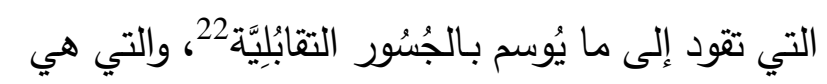


مجلة جامعة الملك عبدالعزيز: الآداب والعلوم الانسانية، م29ع3 ص ص: 257- 281 (2021م) DOI:10.4197/Art.29-3.9

$$
\text { وإِنَّــــا المــوتُ يُسقسى في زوايــاكِ }
$$

وكمثال ليُبنية التقابل في الاستعارة البيت الآتي: ما هاجر الطيرُ من لغوِ ومن لغطِ

فالصورة هُنا عميقة قصدت نعت جهيمان وأصحابه ومعناه في النَّ كثرة الدماء التي تشير إلى كثرة

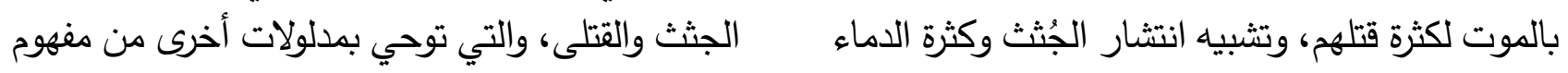
بالسقي، والفعل يُسقى معناه المعجمي: روى وزوَّد، السياق كما ستوضِّحُه الترسيمة الآتية:

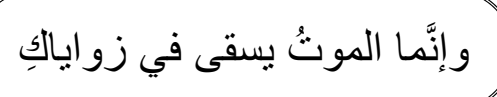
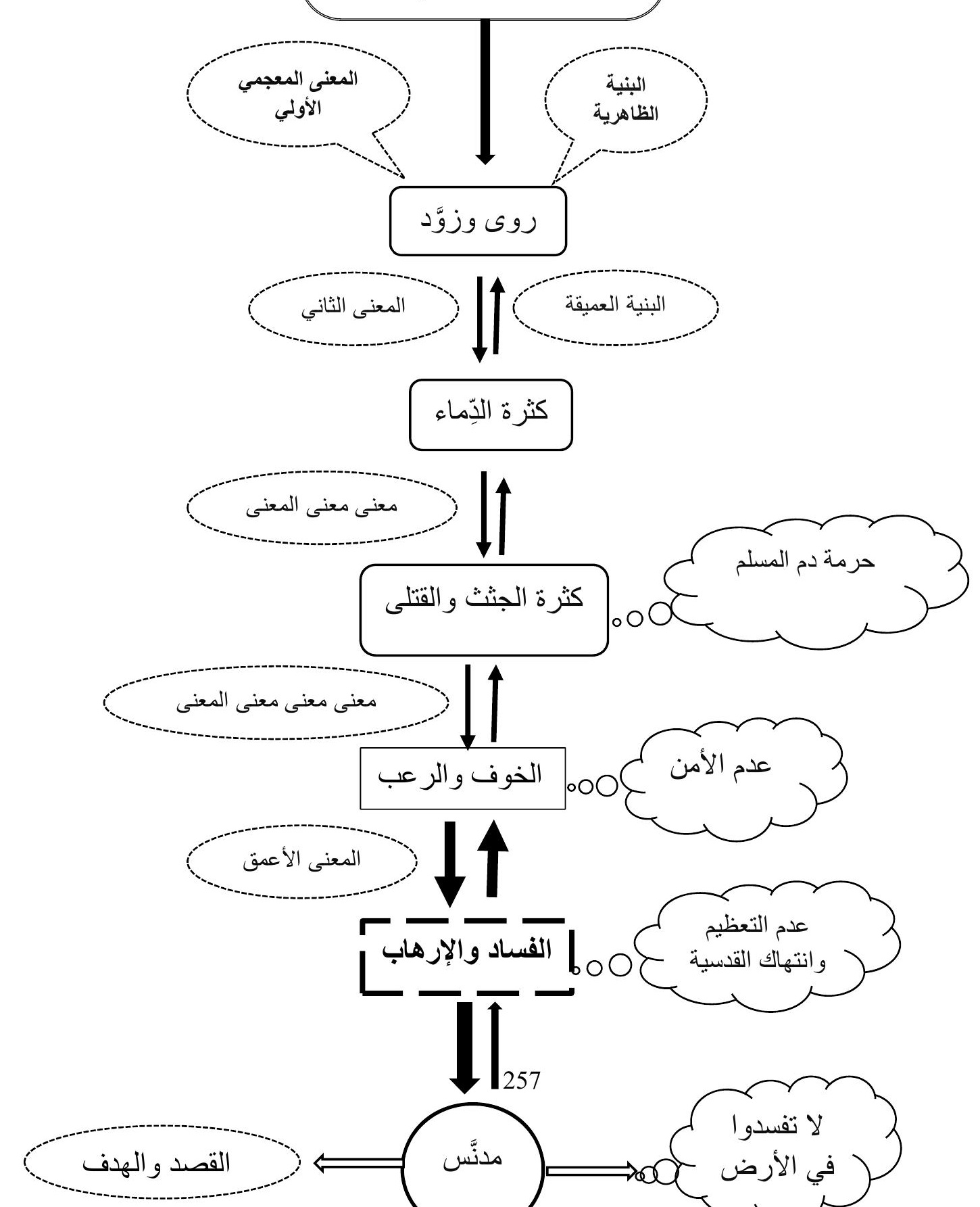


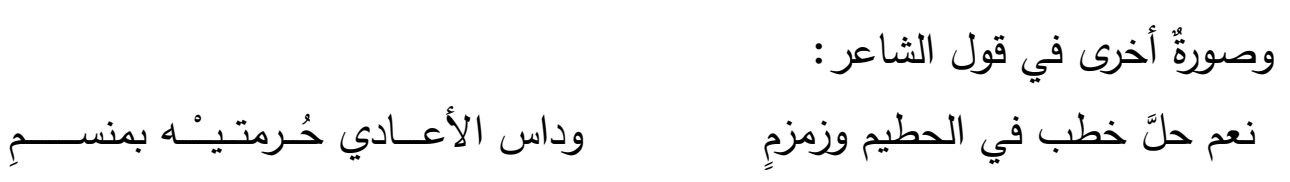

فالصورة البلاغية هنا اقتضت تشبيه الاعتداء على فالاستعارات في القصيدة مُتقابلة، تخدم دلالتي الكعبة الحرم والإفساد فيه بالبعير الذي يدوس بقدمه، ولو والإرهاب/ المقَّس والمدنَّس ما يفيد أن التضاد بين أخذنا المعنى المعجمي الأولي لتدوس لوجدنا أنَّها الدلالتين موجودٌ في الوعي الجمعي، والمقصود منه تعني "شدة وطء الثي بالأقدام"23، والتي تشير إلى (عظّمُوا البيت الحرام وعظّمِوا الشعائر فيه ولا تفسدوا) كثرة القتل والموت، والمؤدية إلى معنى الفساد وهذه هي الدعوى التي من أجلها بُنيت عليها القصيدة والإرهاب الذي بدوره يُشير إلى الخوف والرعب ومنه وقامت الحجج. إلى المدنَّس. وفي رسم صورة أخرى يقول الثاعر :

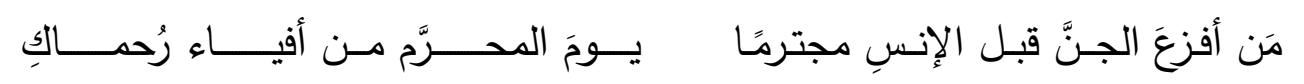
إذ شُبُهت الرَّحمة بالظلال، وهذه البنية الاستعارية تقابلها بنية أخرى في قول الثاعر :

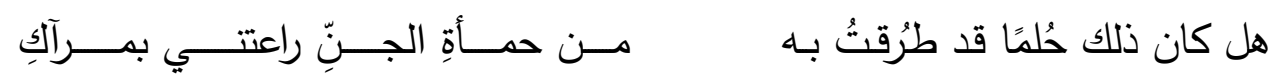
وتتضح ذي البنية في الترسيمة الآتية:24 


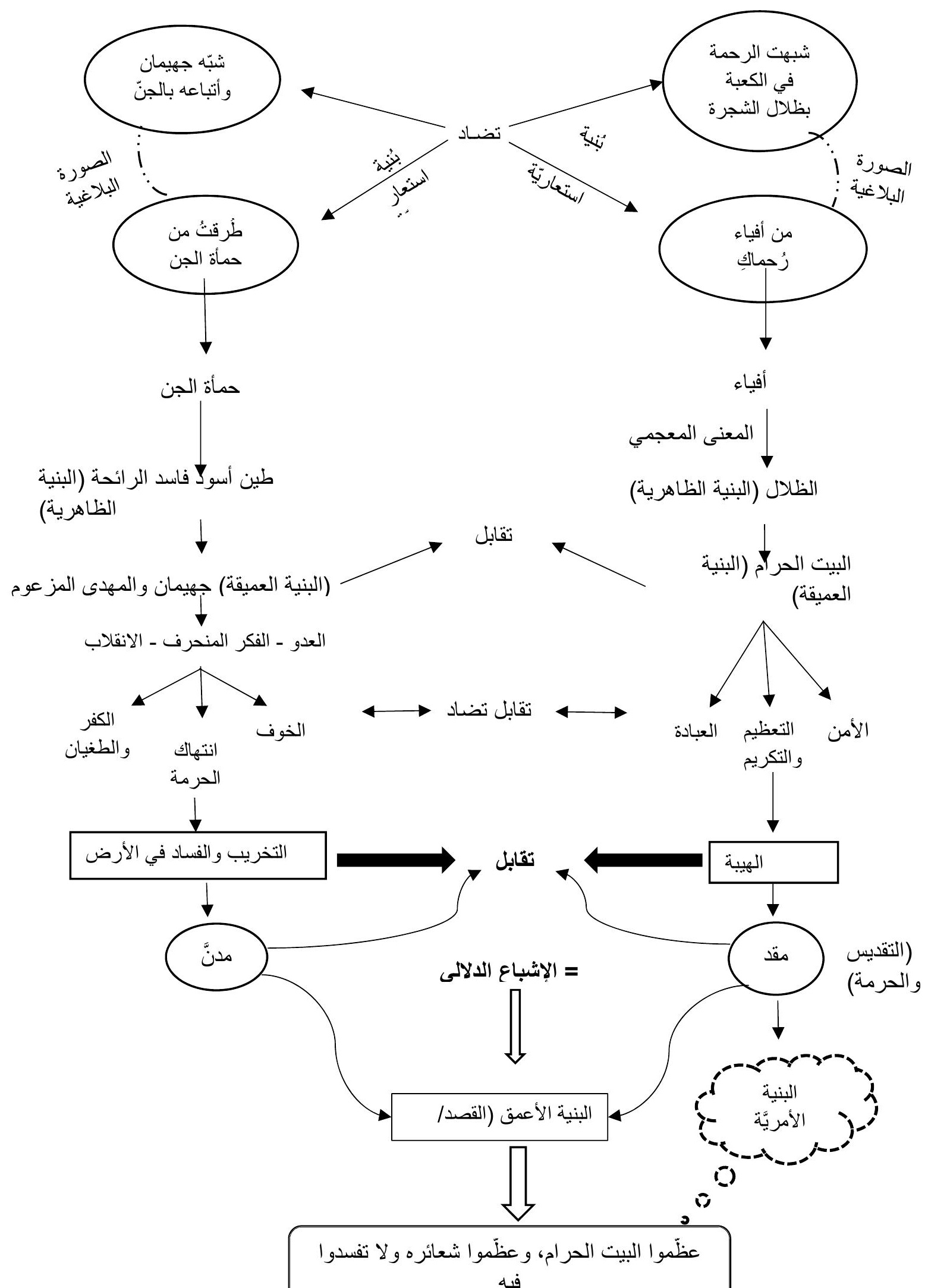


فهذه الاستعارات القائمة على التَّتبيه بتقابلاتها الذهنيَّة عليه شجاعة العربيَّة"28. ومن الوظائف العامة

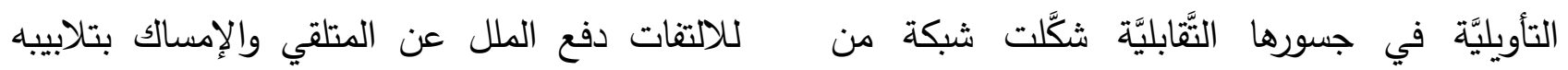

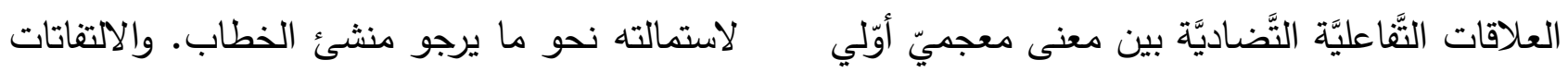

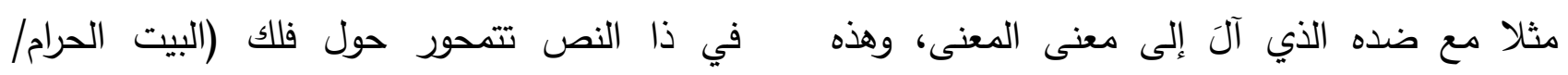

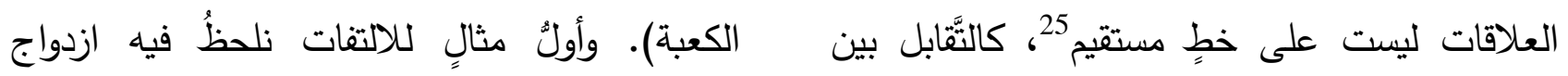
الكعبة والكفر ، أو الكعبة والخوف، وكذلك بين جهيمان صورتين للالتفات معًا في وقتٍ واحد وذلك في البيت والأمن وهكذا، وهذا ما يسمى في البلاغة بالطباق

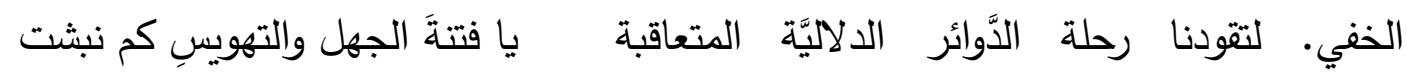

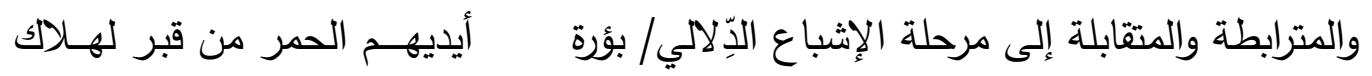

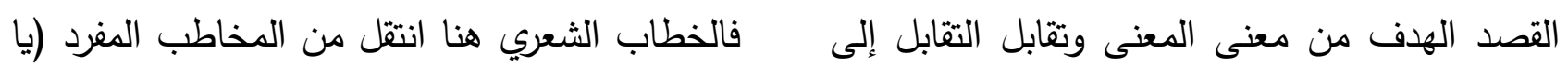

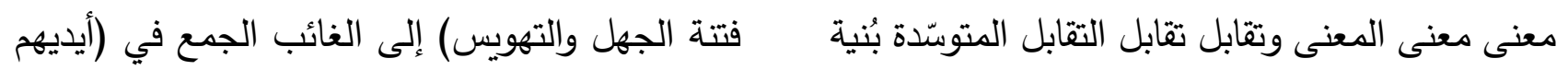

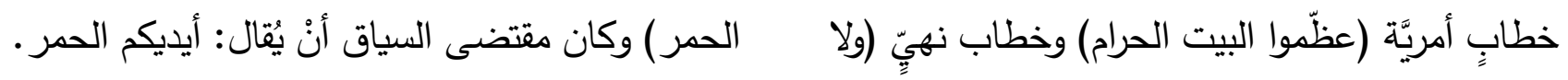

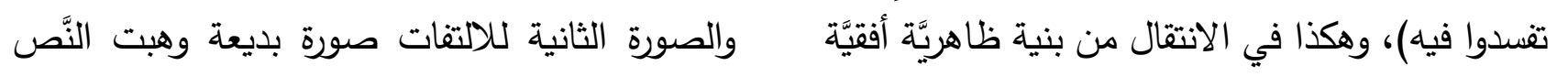

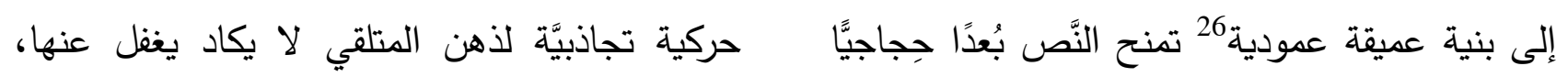

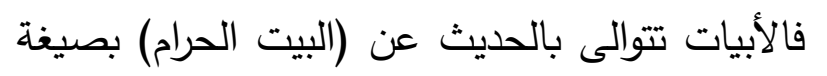
المذكر الغائب إلى البيت:

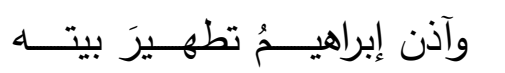

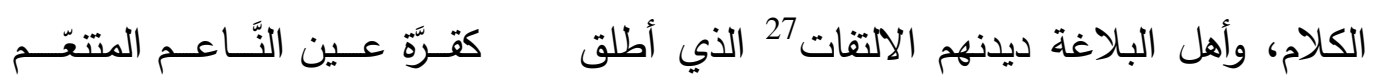
مُطعمًّا بعدة معانٍ تدور في نفس بؤرة النص.

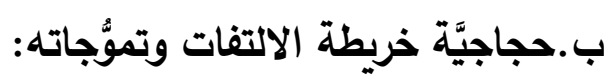

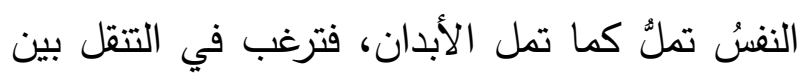

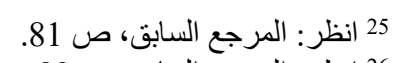

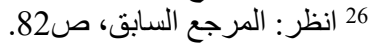
27 انظر: يحيى بن حمزة بن علي العلوي اليمني، الطّراز المتضمِّن لأسرار البلاغة وعلوم حقائق الإعجاز، (مصر : دار الكتب الخديوية، د.ط،1914م)، ج2،

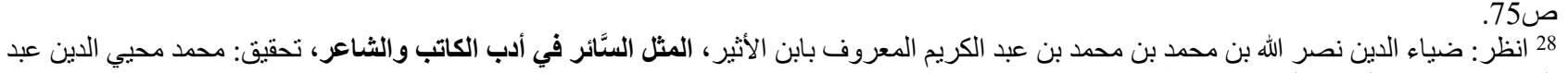

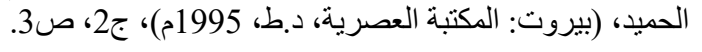


ثم انتقل الخطاب في البيت الذي يليه من المذكر ولا غـــرو أنَّ الله جل جلاله غيور على الدين العظيم المكرم

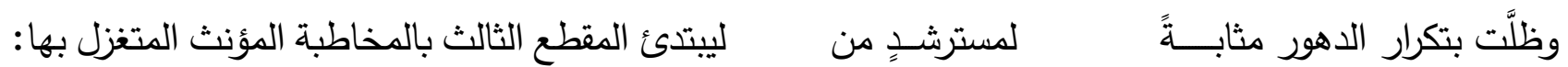

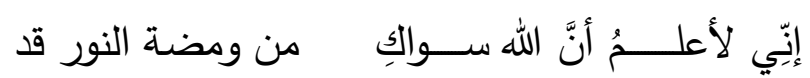

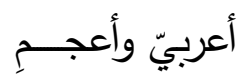

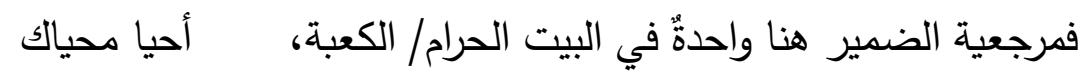
في الانتقال من الجزء إلى الكل والعكس، في الكناية ثم ما يلبث أن ينتقل من المخاطبة المؤنث إلى الغائب المذكر في: والمكني عنها، فالمؤنث هي الكعبة. وصاغ بقدسه في البيت حرمًا يعلو إليه جبين

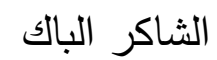

فالتنقلات بين الضمائر، والإفراد والجمع، مع كون مرجعية الضمير تعود على المكون المكاني ذاته (الكعبة/ البيت الحرام) عضَّد موسيقيَّة النص وأكسبها

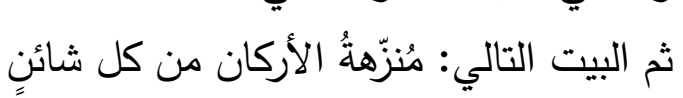

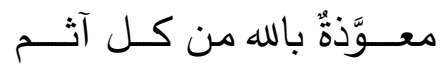
وينتقل بعدها الخطاب إلى الغائب المذكر في: بالئ

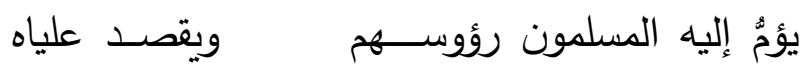
وينتهي الحديث في المقطع الثاني من بحرِ الطويل كثافةً جميلة. بالغائب المذكر : وبني

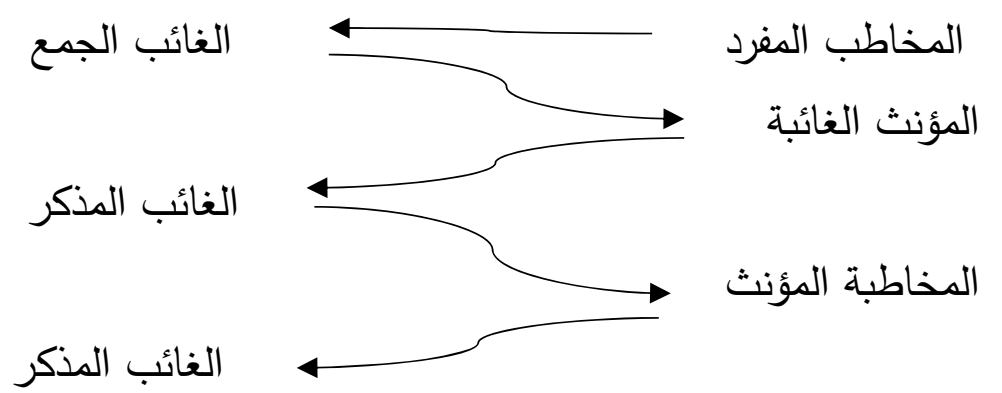

وبعد ورود المخاطَب في تلك المستويات عبر تثكلات الخاتمة

تصاعديَّةٍ مختلفة، وهي: ( الكعبة- ذات المخاطِب-

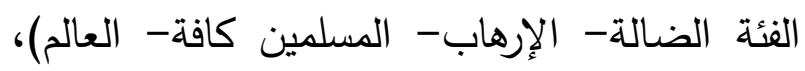

توصلت الدراسة إلى عدة نتائج من أهمها:

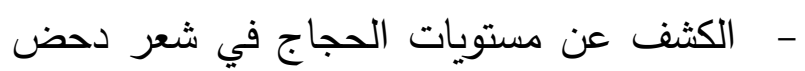

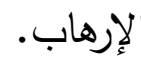

بعد هذا التّطواف والدراسة التحليليَّة الجامعة بين الحجاج والثعريَّة، والوقوف على صميم البنية التحاوريَّة التي تبدو في ظاهرها من مخاطب لمتلقّ ولقّ

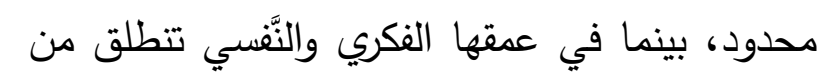
وعي كلِّ مسلم وضميره بل كل إنسان يعي خصوصيّة الأمور القدسيَّة في حياة الثخص وضيد بل إلى الفئة الضالة، 
بروطون، فيليب. (2013م). الحجاج في التواصل.

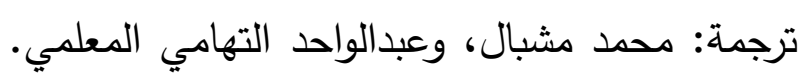
القاهرة: الهيئة العامة المصرية للكتاب، المركز القومي للترجمة. ط1. الحزيمي، ناصر • (2011م). أيام مع جهيمان -كنت مع "الجماعة السلفية المحتسبة". بيروت: الثبكة ناصن العربية للأبحاث والنشر • ط1. الحنفي، أبو البقاء محمد بن أحمد المكي. (1997م). تاريخ مكة المشرفة والمسجد الحرام والمدينة الثريفة البفاء والقبر الشريف. تحقيق: علاء الأزهري وأيمن الأزهري. بيروت: دار الكتب العلمية، ط1. الثيباني، أبو الحسن علي بن محمد الجزري. (د.ت).

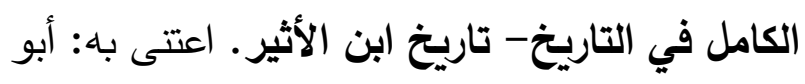

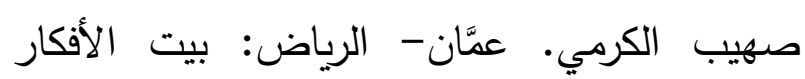

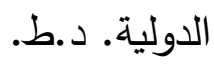

كتانة، نهيل فتحي أحمد. (1999-2000م). دراسة دلة أسلوبية في شعر أبي فراس الحمداني. (رسالة ماجستير في الأدب والنقد، جامعة النجاح الوطنية بفلسطين). المحفلي، محمد. (2016م). النَّص الشعري قراءات تطبيقية-بحوث محكمة. بيروت: الانتشار العربي، ط.1 (1) ابن منظور ، محمد بن مكرم لسان العرب. (1992م).

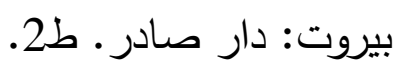

- اتسمت القصيدة بالحيويَّة والحركة المتتامية نتيجة تأثيثها بسلسلة من البراهين الحججيَّة وتكريسها بالصَّريحة منها والضمنيَّة، كحجج الشُّلطة والقيم المشتركة، والأساليب الإنشائيَّة، والسياق التاريخي، والئه

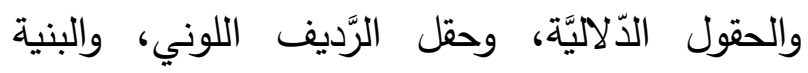
الإيقاعية، وبنية التراكيب اللغويَّة كالبنى التقابليَّة في وليفي الاستعارة، وبنية الالتفات. - تجلّي الالتقاء الحميم بين الثعريَّة والحجاجيَّة في صميم البنية التحاوريَّة. كما توصي الباحثة بدراسة المزيد من القصائد ذات البنات الأغراض المختلفة دراسة حجاجيَّة. قائمة المراجع:

ابن الأثير، ضياء الدين نصر الله بن محمد. (1995م). المثل السَّائر في أدب الكاتب والثاعر. تحقيق: محمد محيي الدين عبد الحميد. بيروت: المكتبة العصرية. د.ط.

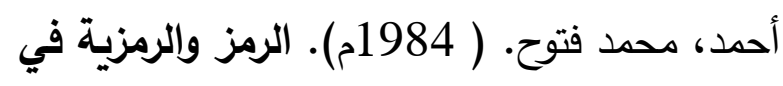
الثعر المعاصر . القاهرة: دار المعارف. ط3. الأزرقي، أبو الوليد محمد بن عبدالله بن أحمد. (2003م). أخبار مكة وما جاء فيها من الآثار. دراسة وتحقيق: عبدالملك بن دهيش. مكة المكرمة:

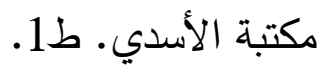

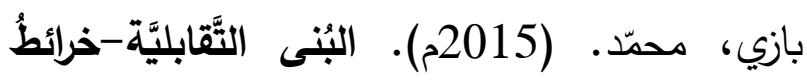
جديدةٌ لتحليل الخطاب. عمَّان: دار كنوز المعرفة. 
(1400هـ). "هل الههي يذبح الأبرياء؟". صحيفة الجزيرة، ع2687.

(1988م)، "سلطان الحبّ والوفاء". صحيفة عكاظ. $.8095 \varepsilon$

(1988م)، "بقايا جراح". صحيفة عكاظ. ع8486.

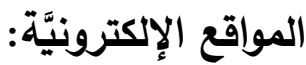

الفيلم الوثائقي حصار مكة،

https://www.youtube.com/watch?v=hXDQSsL $\mathrm{x} 8 \mathrm{qQ}$

https://www.bbc.com/arabic/resources/idt-. sh/idea_arabic

https://alwatannews.net/search/\%D8\%AC $\% \mathrm{D}$. 9\%87\%D9\%8A\%D9\%85\%D8\%A7\%D9\%86 https://www.bbc.com/arabic/middleeast-. 50924634
اليمني، يحيى بن حمزة بن علي العلوي. (1914م). الطَّراز المتضمِّن لأسرار البلاغة وعلوم حقائق الإعجاز. مصر : دار الكتب الخديوية. د.ط. المجلات والصحف: فضل، صلاح. (1981م). ظواهر أسلوبيَّة في شعر شوقي. مجلة فصول. القاهرة: الهيئة الدصرية العامة

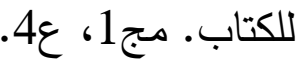
(1979م). "القبض على زعيم العصابة حيًا بعد

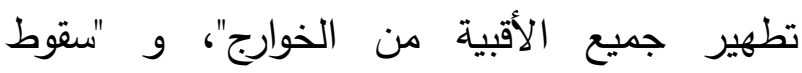
الأضاليل". صحيفة الثرق الأوسط. ع437.

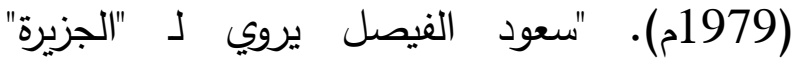
و"السياسة": تفاصيل حادثة الحرج". صحيفة الجزيرة. $2677 \varepsilon$

ملحق

مــا أجمل الصُبـح مسن مرأى محيَّالكِ

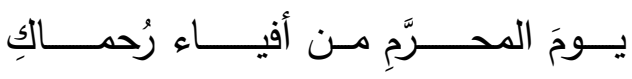

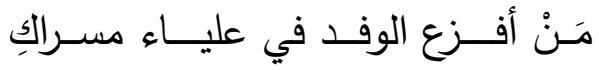

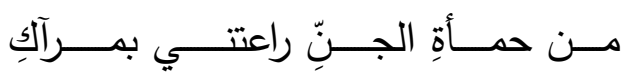
من خوف ذي العرش ما يكفي لتقواكِك

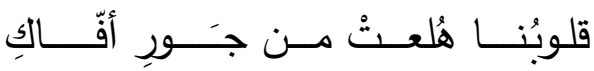

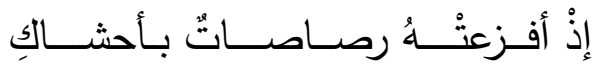

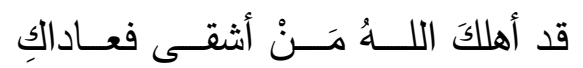

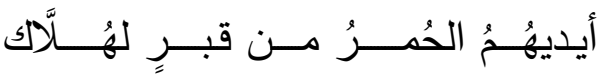

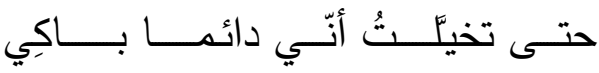
أم شرعــةُ النـاب طمّتَ في سراياكِ

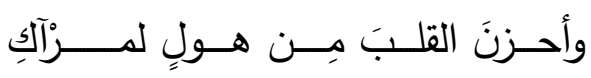

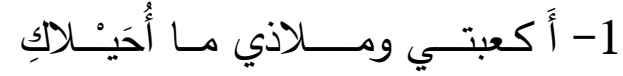

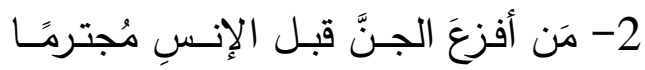

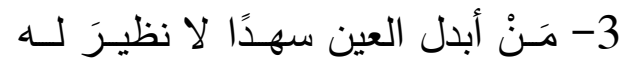

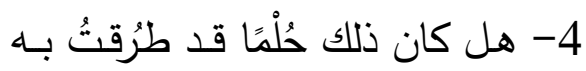

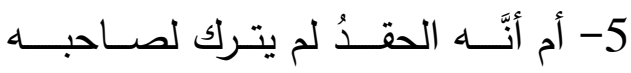

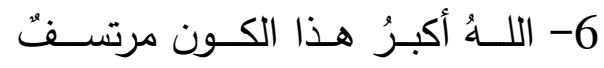

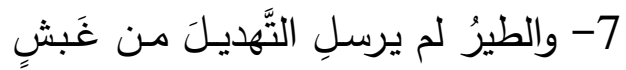

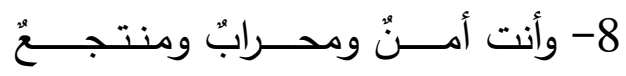

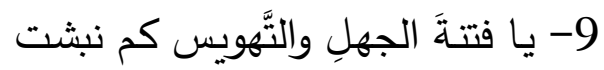

$$
\begin{aligned}
& \text { 10- لم يرقاً الدمع من عيني ولا نضبت }
\end{aligned}
$$

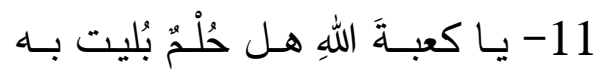

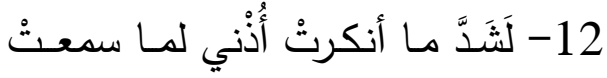


أعـزَّ موطــنِ أمــنِ فــوق حصبـــاكِ

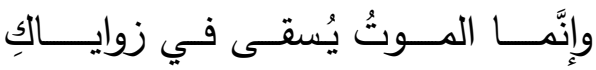

وداس الأعـادي حُرمتيــــه بمنســـــ

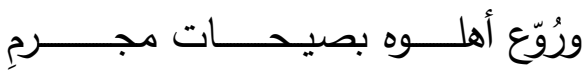

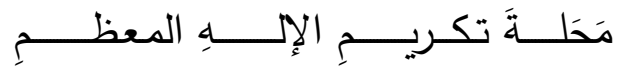

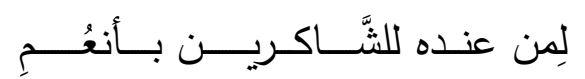
عـن التتـل في البيـت العتيـق المحـرَّمِ

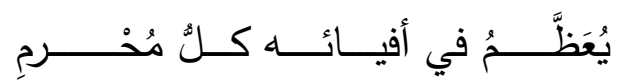

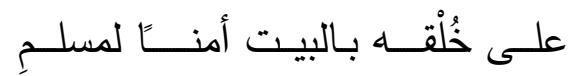

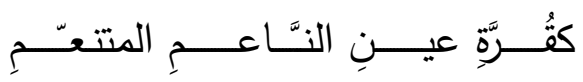

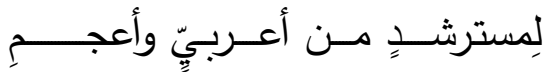

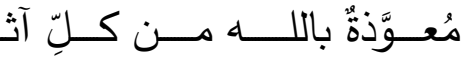

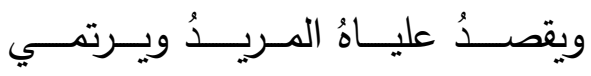

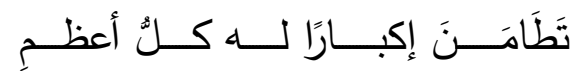

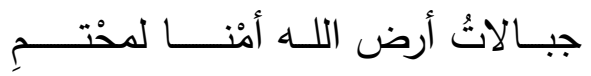

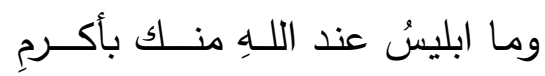

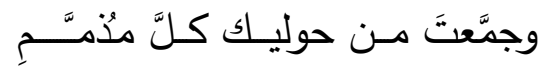

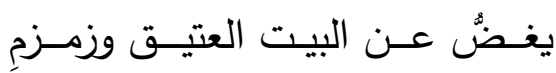
وأحللتَ فيه الخوف والسََّفك باللَّمِ على بال سفَّاح وعن دينـهـ عمـي

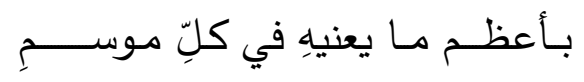
غيـورٌ على الديـن العظيـم المكـرَّمِ مـن ومضـــة النهُور قد أحيـا محيـالكِ يعنـو إليـهـ جبيـن الشـاكـر البـاكي

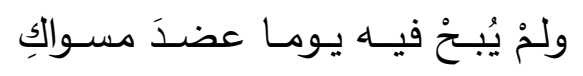

13- هذي الحمامُ وقد طـارتْ مفارقــة 14- ما هاجر الطيرُ من لغُوِِ ومن لغَطِ

15- نعز حلَّ خطُبْ في الحطيم وزمزمٍ

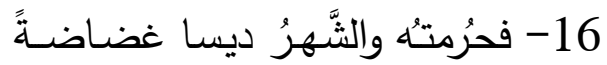
17- وقد كانتـا هُذ كـان آدمُ طينــة 18- بنى اللهُ في عليا السَّماواتِ مثلَهـ 19- فمفتـاحُ هذا العـامِ سُمتيّ محرَّمَّا

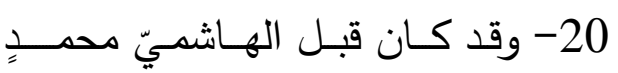

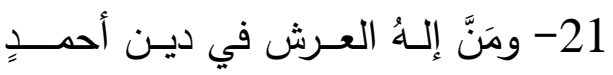

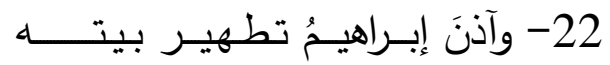
23- وظلت بتكرار الـدهــور مثنابــةً 24- مُنزَّهـةُ الأركــان من كـلِّ شائَـنِ

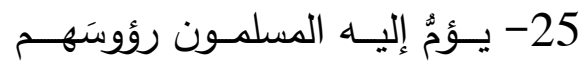
26- إذا ذُكر البيتُ العتيــقُ مكانـــة 27- ولات وربٍّ العرش تعطيك أمنَهُ

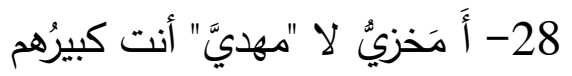
29 - هتكت بفحشٍ ملحدٍ كلَّ حرمةٍ

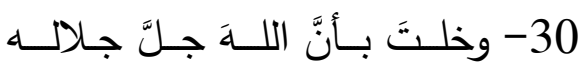

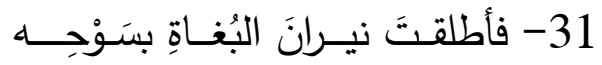

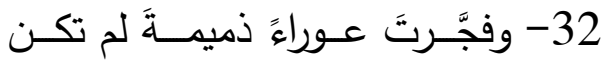

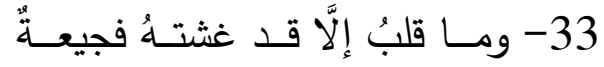

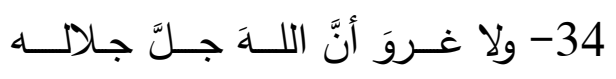

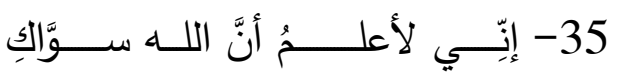
36- وصـاغ من قدسِـِهِ في بيتهـه حردًا

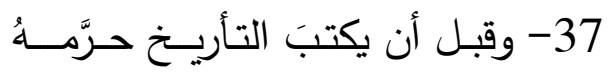


والخيـــرُ وجَّهــــهُ قيـــدًا بتتقـــــوالكِ

طيــرا ليحصــــــالتدقيـق أعـداكِ

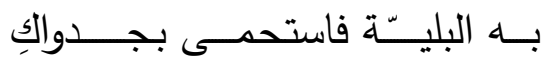

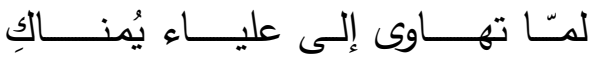

رمـزاً نقاتـلـل مـن يطغـى بعليــالكِ مـا قيمــة العيش إن ديست مزايـالكِ

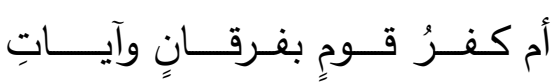

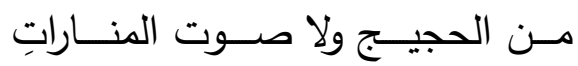

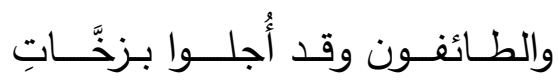
مـن الرَّصــاص ولا شـادٍ بدعـواتِ قد فزت بالخسـر في أهـل الخيانـاتِ تعرضــت لثتــاتٍ فـوق إثـــــاتِ للثــرِّ مسن زمــرةٍ بــاءت بلعنــاتِ

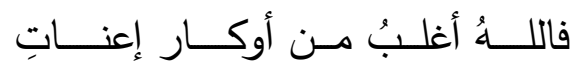

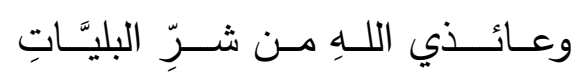
مـن جـانبيهــا عيـــونٌ للعـوايــاتِ

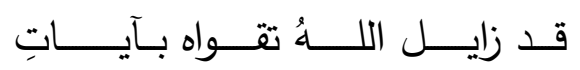

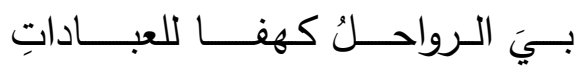
مِن عندِ ذي العرش رغم الخائن العاتي لِي والآلُ والصَّحبُ من ربِّ المَّمواتِ

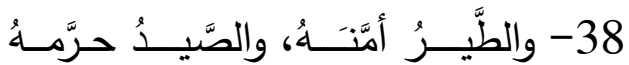

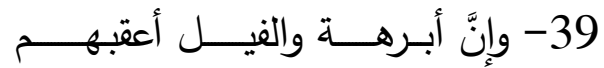

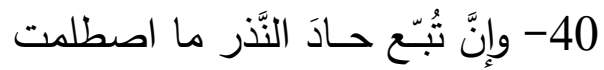

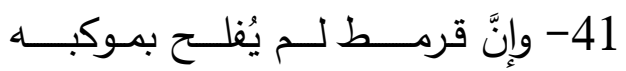
42- هديَّةُُ الِّيــنِ والدنيـا سلمتِ لنـا

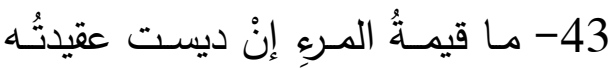

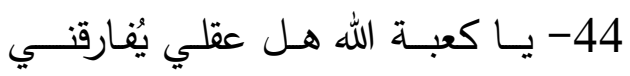

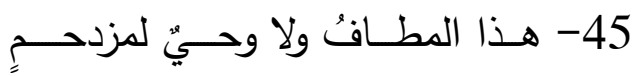
46- والركنُ قد كثف الطاعـونُ جبهتهـ

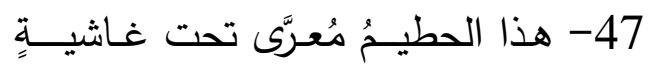

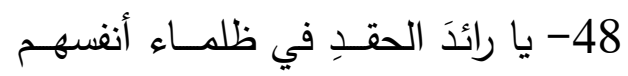
49- الله أكبــــر ، هـــا الديــن كعبتُّــهـ

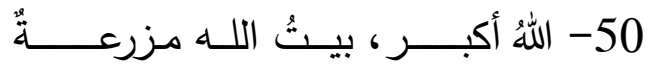

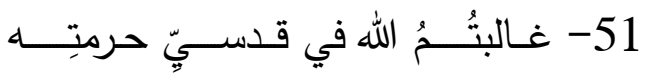
52- يـا مهدَ قدسِ رسالاتِ السمـاء بـهـ 53- حيطانُكِ البيضُ خرساءٌ وقد نطقت

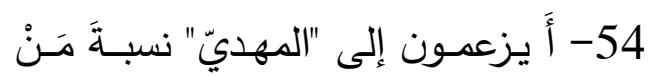

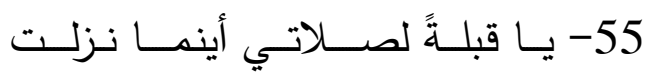

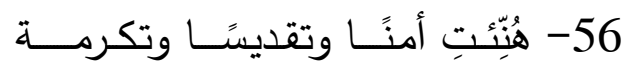

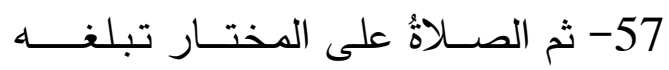



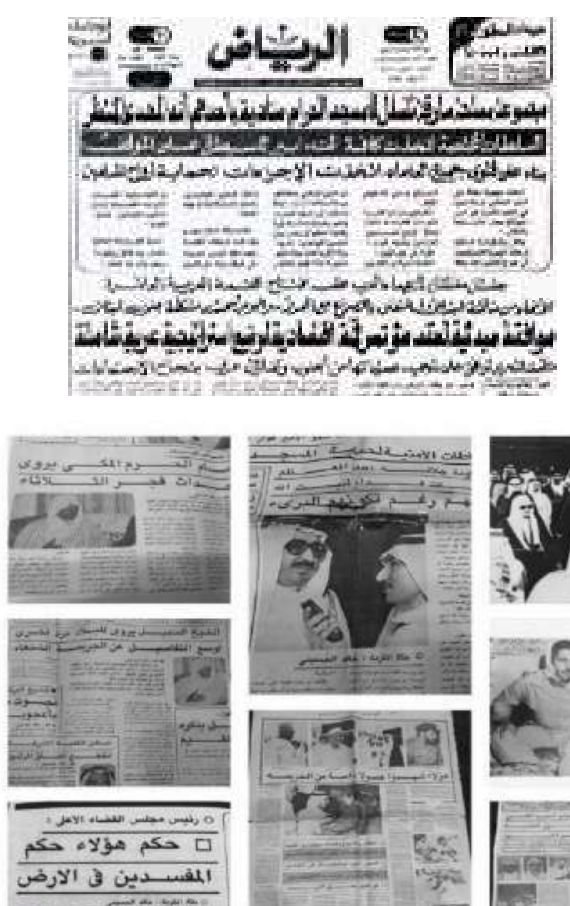

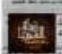
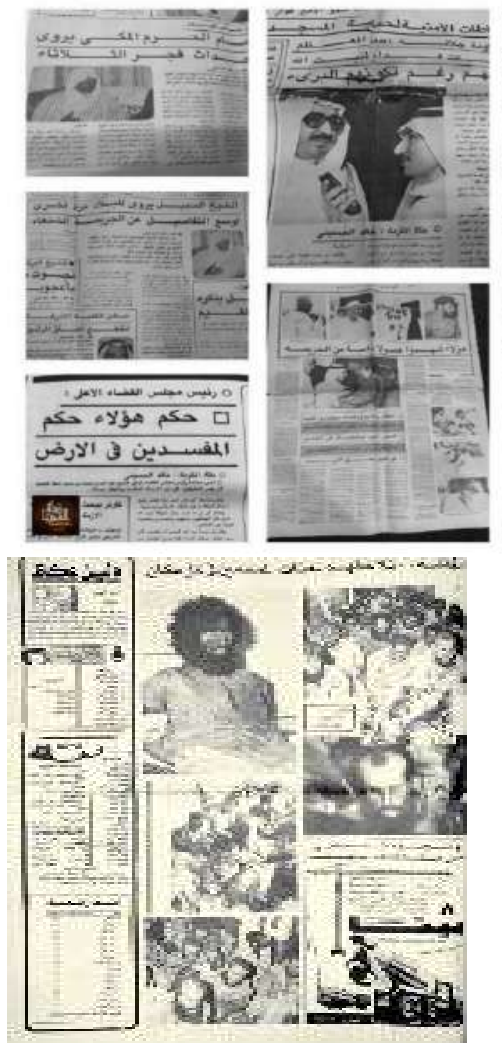
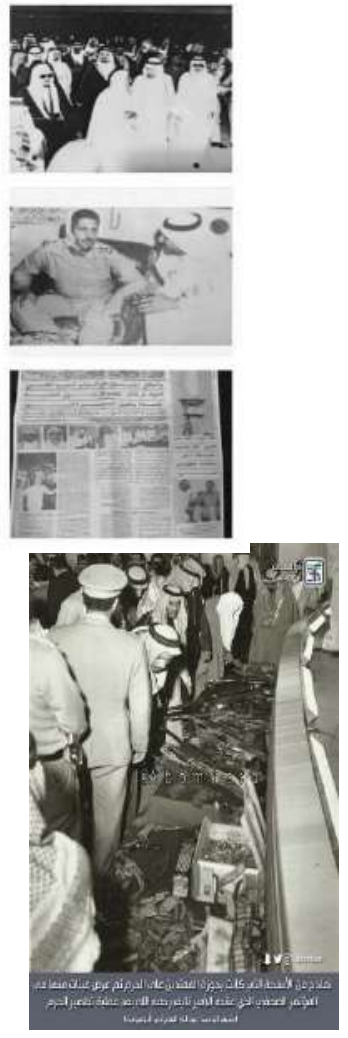
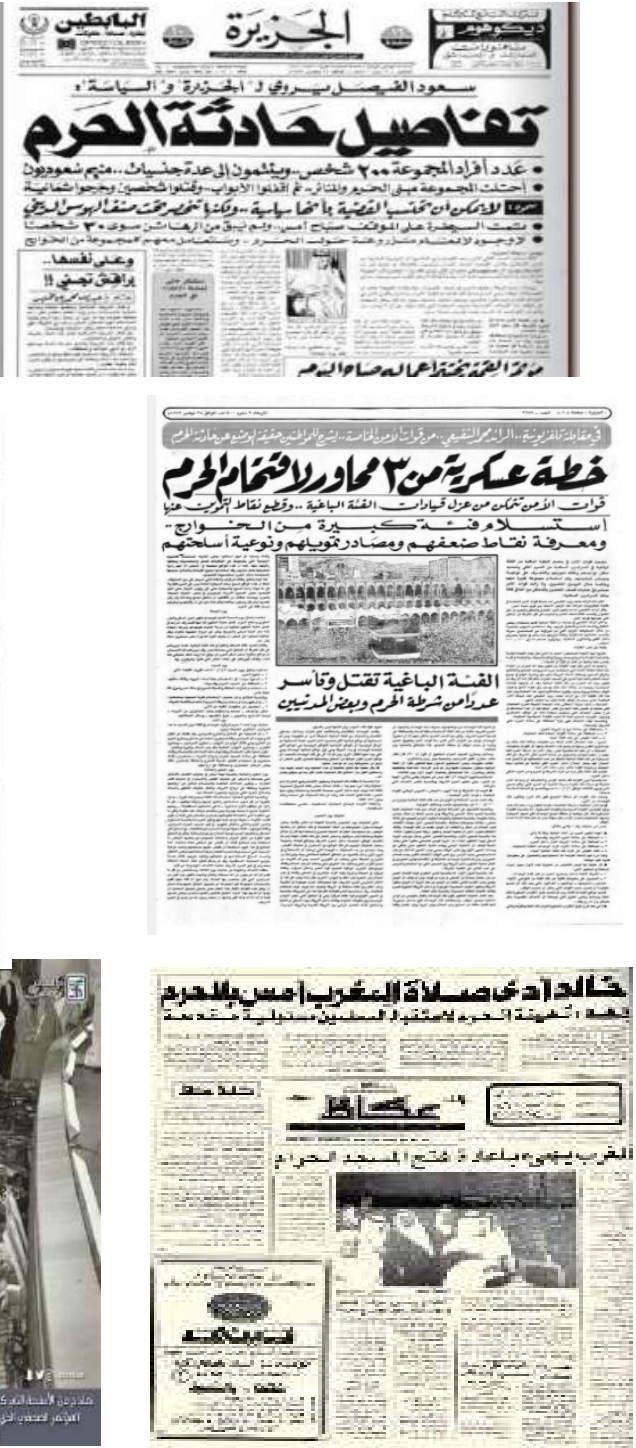


\title{
Poetics of the Tiers of Argumentation in Combating Terrorism; The poem ( $O$, my Ka'bah) as a case study
}

\author{
DR. TAYSIR ABBAS MOHAMMED ALSHARIF \\ Assistant professor of rhetoric and criticism \\ Dept. of Arabic language and literature \\ Faculty of Arts and Humanities \\ King Abdulaziz University- Jeddah
}

\begin{abstract}
Its cruelty has gone beyond perception of the human mind. Among the most unforgettable criminal and atrocious terrorist events is that attack of Juhayman Al-Otaibi on the the Holy Mosque of Makkah perpetrated out of oppression and aggression. Juhayman falsely claimed the appearance of the awaited Imam Al-Mahdi and that people were obliged to pledge allegiance to him causing many lives to be lost.

This dire incident was received with condemnation and excitement by the Muslims all over the worlds. This poem - the subject of the research - was one of the means of refuting terrorism and condemning it by summoning different types of argumentation.

The research has committed itself to reading and analyzing the text argumentatively to affirm the applicability of this approach to unveil the poetic styles in antiterrorism woe-charged poetic texts. It further highlights the multimodal convergence of argumentation, poetry and terrorism in persuading the readership via multiple constructive levels and different explicit and implicit arguments, such as authoritative arguments, common values, thematic and historical styles methods, color connotations, rhythmic and linguistic structures.
\end{abstract}


تيسير بنت عباس محمَّد الثَّريف 